
of Geothermal Development in Lake County, CA

C. West Churchman, Harold G. Nelson, and Kreg Eacret 


\section{DISCLAIMER}

This report was prepared as an account of work sponsored by an agency of the United States Government. Neither the United States Government nor any agency Thereof, nor any of their employees, makes any warranty, express or implied, or assumes any legal liability or responsibility for the accuracy, completeness, or usefulness of any information, apparatus, product, or process disclosed, or represents that its use would not infringe privately owned rights. Reference herein to any specific commercial product, process, or service by trade name, trademark, manufacturer, or otherwise does not necessarily constitute or imply its endorsement, recommendation, or favoring by the United States Government or any agency thereof. The views and opinions of authors expressed herein do not necessarily state or reflect those of the United States Government or any agency thereof. 


\section{DISCLAIMER}

Portions of this document may be illegible in electronic image products. Images are produced from the best available original document. 


\section{LEGAL NOTICE}

This report was prepared as an account of work sponsored by the United States Government. Neither the United States nor the Department of Energy, nor any of their employees, nor any of their contractors, subcontractors, or their employees, makes any warranty, express or implied, or assumes any legal liability or responsibility for the accuracy, completeness or usefulness of any information, apparatus, product or process disclosed, or represents that its use would not infringe privately owned rights.

Printed in the United States of America

Available from

National Technical Information Service

U. S. Department of Commerce

5285 Port Royal Road

Springfield, VA 22161

Price; Printed Copy, \$ 6.50 Domestic; $\$ 13.00$ Foreign

Microfiche, $\quad \$ 3.00$ Domestic; $\$ 4.50$ Foreign 
CONTENTS

Section One:

Section Two:

Section Three:

Section Four:

Section Five:

Section Six:

Section Seven:

Section Eight:

Section Nine:

Section Ten:

Section Eleven:

An Introduction ............ 1

On Morality and Ethics.......... 9

The Vanishing Community ......... 22

Case Study of Pre-Development Plaming-

Lake County. . . . . . . . . 30

Methodology for Research. . . . . . 45

Lake County Geothermal Energy Resource. : . 49

Decision Making . . . . . . . . 59

Planning Commission Hearing . . . . . . 71

Communication Examples. . . . . . . 74

Benef1t Tracing . . . . . . . . . 94

Response to Issues Raised by the Report

of the State Geothermal Task Force . . . 98

Section Twelve: Conclusions and Recommendations . . . . 105

Acknowledgment. . . . . . . . . . . . . . 108

References...................... 109

This wport was prepared at an wccount of work

mponered by the United Stutes Govemment. Nither

United States nor the United states Dopitnent

Enery, nor any of their employees, nor any of

contractors, subcontractons, or their wor

any warranty, express of tmplied, or essumes any boal

lability or responsibility for the sceuracy, completeness

of wefulnoss of any informption, apparatus, product or

process disclosed, or represents that th use would not 


\title{
VALUE DISTRIBUTION ASSESSMENT OF GEOTHERMAL DEVELOPMENT IN LAKE COUNTY, CALIFORNIA
}

\author{
Lawrence Berkeley Laboratory, Berkeley, California 94720
}

SECTION ONE: AN INTRODUCTION

There are many ways of assessing the impact of development which are being used today. Indeed, this generation may be regarded by later generations as the initiator of careful technological planning. If so, and this is a wise move on our part, then it is important that we explore the various meanings of "assessment," lest we ignore some important ones. It is common, for example, to contrast physical ("hard") assessment with socioeconomic ("soft") assessment, as though the two were exhaustive.

This study explores a meaning of assessment which the investigators believe has not been adequately explored before, which, although peopleoriented, is not a socioeconomic appraisal. We have called this approach "value distribution assessment," which, we believe, has considerable historical justification.*

The meaning of value distribution assessment can be compared with socioeconomic assessment as follows:

Socioeconomic Assessment: the determination of the aggregate benefits and costs, including the economic and social, resulting from a proposed or actual development, with the intent of comparing such a development with alternative plans.

Value Distribution Assessment: the determination of the distribution of benefits and costs, including the economic and social, but also people's perceptions of how they are being treated, which result from a proposed or actual development, with the intent of comparing such a development with alternative plans.

\footnotetext{
"For example, Immanuel Kant's Foundations of the Metaphysics of Morals,
} 1785. 
As in the case of socioeconomic assessment, we use a term like "loss" to connote the negation of value, so in the case of value distribution we use "inequity:"

Inequity refers to an action in which someone loses so that someone else may gain (in Kant's terms, "being treated as a means only").

Thus the difference in meaning of the two labels is that one emphasizes the total and the other the distribution of the total. In practice, of course, assessments tend to have a mixture of the two approaches, but the overall emphasis to date has been on the socioeconomic approach.

It should be emphasized that the two approaches differ not only in meaning but also in methodology. The socioeconomic approach naturally depends on quantitative measures such as economic benefits and costs, whereas the value distribution approach depends on qualitative descriptions since it is trying to describe how people feel about proposed changes, and such feelings usually defy quantification. The investigators believe that in the preliminary exploration of value distribution assessment such matters as questionnaires and comprehensive interviews should be postponed until we understand better the inequity climate of the development process.

We have attempted to begin the design of a value distribution assessment process for geothermal development in Lake County, California. It is estimated that Lake County is very rich in its geothermal resource. The proposed development consists in drilling exploratory wells, and if enough steam is found, indrilling additional wells, constructing power plants and building overhead wires to convey electricity to other parts of the state.

Geothermal energy is only one of Lake County's resources. It is a beautiful county where many people have sought retirement or a place to go to avoid the pressures of an industrialized community. Many of these people do perceive geothermal development as a threat to their way of 1ife. For example, one area of Lake County, Cobb Valley, has been viewed by its residents as primarily a residential area. Those who are pressing for geothermal development would like to see several plants located in the Valley. This is seen as a move towards industrialization by a number of residents. Of course, some of the residents see geothermal development as highly beneficial since they own land which they expect would eventually 
be leased. But others see the development as the end of a style of life. of course, there are a variety of other viewpoints among the residents which we have also studied.

Those who are deeply concerned and unhappy about the way in which geothermal development is taking place, visualize a complete transformation of their county, with up to forty plants, perhaps six hundred wells, five or more industrial parks, increased taxes, roads, overhead wires, etc. This vision may not be accurate but those who hold it are certainly paying a cost in terms of the quality of their present lives.

Since value distribution assessment determines the distribution of benefits and costs, it will also determine inequity, where some people see themselves being forced to do things which they clearly do not want to do. Equity is as much a human value as economic benefit. For example, strip mining, coal gasification and similar developments produce drastic changes in the environment which virtually ruin human communities, not to mention wildlife and plant life.

Often value distribution assessment conflicts with economic assessment in that certain people may benefit economically, but other people may suffer by being forced to live in ways contrary to their expectations. Wise judgment consists of understanding both the total and the distribution of benefits and costs and attempting to make the best decision in the context of the conflict between the two.

In our attempt to do value distribution assessment, we have posed nine basic questions.* These formed the tasks of our proposal (October 1976).

1. Who should the client be? That is, who has the right to be served by the system that is relevant to the proposed geothermal development in Lake County?

2. What should be the goals of the system? This is just another way of getting at the first question because it asks how the client should be served

3. Should there be a measure of performance for the system? Such a measure, if it existed, would provide decision-makers with a way of judging whether a proposed change is a real improvement.

* See C.W. Churchman, Design of Inquiring Systems, Chapter III, Basic Books, 1970. 
4. Who should the decision-makers be? A decision-maker is one whovia his resources-can produce changes in the measure of performance of the system's components and hence change in the measure of performance of the system.

5. What components of the system should the decision-makers control? The components in question are those that will coproduce the measure of performance of the system. In the case of Lake County, we want to know what can be changed by an act of the decision-maker and what is beyond his control.

6. What should the environment of the system be? This is a problem of trying to bound the system and consists of determining exogenous and endogenous influences. The question concerns what should be taken as given and what should be considered a candidate for change.

7. Who should be the planners of change in the system? A planner is someone who conceptualizes a change and assesses its value. If he/ she deems this value to the "best," then the planner attempts to implement the change (no change is, of course, one alternative).

8. How should plans be implemented? Implementation is a process which is designed to transport conceptual plans into actions (changes).

9. What should be the design of the control of the implemented plan? "Control" means the ability to change a process in the right direction if the process gets off the track.

To the first question, who is being served by geothermal development and who should be served, the obvious answer is that the people of the State of California should be served in terms of energy, but it is clear to us that this obvious answer is quite inadequate. We have attended a number of hearings both in the county and in the state concerning geothermal development, and in all of these hearings practically no mention has been made of the attitudes and perceptions of the residents of the county, both present and future, who will lose by geothermal development. These are people who do not own property, but do not wish to live near overhead wire and plants, or even industrial complexes based on non-electric utilization of geothermal power. Then, of course, there are a number of people (the number is yet to be determined) who will benefit economically and who apparently feel that the environment will not be drastically altered. 
It may reasonably be asked why we have concentrated on the residents of Lake County in this study. We have done so because (1) the residents are those who are most directly affected in terms of their lives (a user of Lake County electricity in Oakland is probably completely unaware of the environmental changes in the county) and (2) there are many similar situations in the U.S.A. and the world in which development has had deleterious impacts on residents.

In the case of value distribution assessment, future generations are of critical importance, because present development may so change the environment that they can never enjoy the peace and beauty that Lake County has today. Hence, one value distribution concern is that the County develop so that a minimum of inequity occurs relative to future generations. It should be noted that socioeoconomic assessments often discount for future values, whereas value distribution assessments do not; inequity with respect to the future counts just as much as inequity with respect to the present.

The second questions is simplya clarification of the first. It asks how the clients should be served. That is, what are the appropriate goals of geothermal development? At the present time there is not a clear concensus on these. Some believe that by the year 2020 a full-blown development should have taken place with possibly as many as sixty 100megawatt plants and perhaps 10 industrial parks spread throughout the County. others feel that the important goal is to keep the quality of the environment intact and proceed slowly with the development. In this report we have tried to examine aspects of these conflicting goals and have not tried to reach a final conclusion. We believe that both the residents of the county and the interested agencies and private companies should be far more aware of the conflict of goals than they are at present. Indeed, the conflict is one aspect of the "distribution" of benefits and costs.

The third question which demands answering by all those involved in the development is what should be the measure of performance? That is, the measure by which one can determine whether development implies progress or retrogression. obviously, given the conflict in goals, there 
is also a conflict concerning the appropriate measure. Apparently some interested parties believe that the appropriate measure is the number of megawatts produced at some "reasonable" cost. A considerable group believes that the measure of performance is the quality of life in the County. Another measure of performance may include the percentage employed. Again, we are attempting to bring out the nature of the many different and conflicting measures of performance so that wiser decisions. can be made.

The fourth question is concerned with the decision makers, who they are and who they should be. We have included in Section Seven of this report a "map" of the decision-making body relative to decisions about geothermal development in Lake County. The "body" includes the residents, the county government and administration, a regional planning group, several state agencies, quite a number of federal agencies, public utility commissions and private companies (including oil, electricity, banking, real estate). The decision-making body can best be described by that picturesque English word "mess:" it has no recognizable head and very little heart, it jumps in unexpected directions when prodded, though just as often it refuses to move, the interrelationship between the parts is ill-defined, and it keeps growing. We hasten to add that this kind of decision-making body is not unique to Lake County development. It exists everywhere in the human world. But there is much to be said in favor of trying to create a head and heart for the beast; our mapping is just a first step in this direction. Our analogy, like all analogies, runs the risk of deception. We do not mean that the head should be a strong leader, or an elite made up of experts. Indeed, this is the exciting challenge of any democratic society: to create a society with a head which is not dominated by one class of individuals.

If the decision-making body had a head, it would begin to assess its resources and options, the fifth question on our list. Thus, we have tried to take a second step by trying to determine what a head should know in order to decide well. It needs to know what it can change, and how, in order to best serve the client, and it needs to understand those things which constrain its actions, the "environment" (the sixth question). Thus, a suitable head would be able to determine what it can and should 
change, and what it cannot, and would be able to justify its determinations. We should hasten to add that none of these determinations are obvious, given the present conflict of values mentioned above. Since the present decision-making body lacks a head, it will decide in ways that at best only haphazardly serve the client, and of course, haphazardly harm the client. Given the mess, we can at least say that the decision-making body is not consciously vindictive.

When we said a decision-making body with a head should do all the above, we mean that it should plan. How it should plan is our seventh question, and the eighth is the relationship between planning and decisionmaking. When we said that the present decision-making body jumps unpredictably when prodded, we meant that in its parts it tries to cope. Thus, the Supervisors and Planning Commission of Lake County are parts of the body; when a private company requests a permit to drill an exploratory well, these parts are prodded and they attempt to respond, not on the basis of an overall concern for the future of the County, but in terms of procedures and pressures. In Section Eight of this report we have illustrated just such a prodding and jumping of the body. Our eight question is how decision making can be responsive to rational, overal1 planning.

Finally, a sound and healthy decision-making body would be deeply concerned about the lives of future generations, and would attempt to design guarantees that nothing it decides would permanently mar the quality of life of those who in the future choose to live in Lake County. Our ninth and last question addresses the question of how to design such a guarantor.

The reader may require a guide to the remaining sections of the report. We start in Section Two with a very broad topic, the philosophical justification of value distribution assessment, which is to be found in the history of human thought on ethics. Then we narrow the discussion somewhat in order to talk in general terms about community-what it means, how it is created and often destroyed. Next, we narrow even further to a discussion of Lake County as a community. In Section Five we describe the research methods we have used in order to address the nine questions given above. The next six sections of the report present our results. It is to be emphasized that some of these are inevitably incomplete, since this project 
was rather abruptly terminated at the end of its first year. Finally, the last section contains our recommendations.

Persons desiring further information or wishing to comment on the report should write to Professor C. West Churchman, School of Business Administration, 350 Barrows Hall, University of California, Berkeley, California, 94720.

Th1s work was done with support from the U.S. Department of Energy. 
SECTION TWO: ON MORALITY AND ETHICS

The distinction made in the Introduction between socioeconomic and value-distribution assessments has had a long tradition in the writings on human ethics. One of the research team members, Dr. C. West Churchman, is currently writing a book on the "systems approach and its enemies." We reproduce here an adaptation of the chapter on the ethics of the systems approach.

THE SYSTEMS APPROACH AND ITS ENEMIES

Chapter V: Ethics of the Systems Approach

\section{Why Ethics?}

We have seen from an examination of the tradition of the systems approach that the problem of human destiny-i.e., of ethics - has been central in historical writings. However, today we find a most curious phenomenon in which books on systems analysis, planning, operations research, etc. rarely consider ethical issues. I know of one rather we11-respected school of public policy which up to recently offered no courses in ethics, and discouraged discussion of ethical issues in its seminars.

One reason that is offered for such a peculiar educational policy in a school of public policy is that to mature, public policy requires a background of careful analysis, based on hard and solid data, in the "tradition" of the "scientific method." But, so goes the argument, ethical issues are slippery and seem not to be based on any universally acceptable analysis and data. Yet in the sixteenth and seventeenth centuries, which founded the tradition of the scientific method, ethical issues were central to all those who thought and wrote about human inquiry. The twentieth century intellectual has often become an aberration in the evolution of human learning, by blocking off critical issues of knowledge because his methods are not adequate to address them.

There are a number of tactics that can be used to keep out the monstrous ethical issues which clearly surround the systems analyst. One is to insist that he who pays the bill for the analysis must state 
his goals clearly. But this lets in too much: crime, exploitation, cruelty, neglect, etc. Another is to adopt a "disaster" ethic: never recommend a policy which has a "reasonable" chance of producing human disasters (starvation, radiation, disease, excessive air or water pollution, floods, etc.). This is a little better, but it assumes that human life, no matter how it is lived, is better than death or a diseased body. In other words, this suggestion makes a strong assumption about system separability: that the values associated with disaster can be separated from other ethical values.

I think one reason a professor may discourage the discussion of ethical issues among his students in class is that he himself has no satisfactory answer; as a person, he may hold strong ethical beliefs, but he cannot "objectively" profess these since his intellect recognizes that his ethical principles are all subject to doubt. What he fails to realize is that ethics is not a body of theory substantiated by facts. Instead ethics is a process of continuously - and I think eternaliydiscussing and debating and occasionally fighting over the issues. In short, ethics is a dialectical process in which all humanity, past, present and future, must take part. The compulsive will want to know whether the discussions "get anywhere," or whether it is merely a battle of abstractions that rarely if ever has anything to do with human affairs in action, The response is that the debate must include action as one of its components: ethics has to flow through real actions as well as real ideas. It dries up once it is locked in a debate between academics who have rarely seen or touched the vital ethical body of real human beings in their daily lives.

Hence, as we proceed, we"11 be constantly introducing as part of the theme the way in which people interact with people in the ethical mode. The compulsive may still want to know whether all this gets us anywherei.e., whether there is overall maturation, evolution or progress; but perhaps if he emerses himself a bit in the history of man's struggle with the problem of ethics, he' 11 begin to realize that he himself is a part of this history.

2. An Historical Debate: Kant and Bentham

If I were to follow the policy of this book, I should now have to turn to the history of ethics to show how the process has occurred among our 
predecessors in the debate. But fortunately, and surprisingly, there was a "synchronous" debate in the eighteenth century, which is so rich that it virtually contains the essence of the whole historical process. I call the debate "synchronous" because the parties in the debate apparently were not aware of each other's existence and yet wrote at the same time. The debate is between Kant and Bentham, both of whom were deeply involved in considerations of human ethics, beginning about 1781 and culminating their writings by the end of that decade, Kant in Koenigsberg, Bentham in London.

\section{Bentham}

We can begin with Bentham. It was Bentham's intent to design a methodology for assuming the worth of a proposed piece of legislation. In this sense, he was a founder of the class of "evaluation" or "assessment" techniques which have infiltrated into every aspect of government today: costbenefit, technological assessment, socioeconomic assessments, etc. What is required for so bold a venture is to discover the source of all human value. Bentham takes this task to be relatively simple: "Nature has placed mankind under the governance of two sovereign masters, pain and pleasure. It is for them alone to point out what we ought to do, as well as to determine what we shall do. On the one hand the standard of right and wrong, on the other the chain of causes and effects, are fastened to their throne. They govern us in all we do ..." (Introduction to the Principles of Morals and Legislation, Chapter I).

This principle of human values was not new with Bentham, who borrowed it from David Hume, who himself was one in a long line of philosophers who believed that the only "realistic" approach to ethics is to be found in everyman's search for happiness. Not only is the principle realistic ("after al1, once you get rid of rhetoric and abstract garbage, everyone is out for himself'), but it also can be given a more or less rigorous form. This point seems to have been recognized at least as far back as Epicurus (341-270 BC), who, I think, would have been very pleased had cybernetics been discovered in his day because he was struggling to develop a stability model for the flow of pleasure and pain in the human body,

Bentham, who was certainly not the deepest of thinkers, almost immediately takes an enormous step in his quantification of the pleasure base: "a measure of government ... may be said to be conformable to ... principle of utility, 
when in like manner the tendency which it has to augment the happiness of the community is greater than any which it has to diminish it." (ibid.) Community, he says is a fictitious body made up of members. The quantification now emerges as the addition of the pleasures of the members minus the pains. The size of the community is determined by the number of "interested parties," a concept that, as we have seen, istill remains frustratingly vague, for "interested parties" are, I suppose, the same as my category "client," and we have no sold methodology for determining the class of clients. Nor is there any clear explanation as to why the individual who "realistically" takes care of his own interests should now operate under a "principle of utility" which declares that the community government should maximize the pleasures of all members.

Finally, Bentham's program becomes bogged down in the meaning of pleasure and pain, both of which are elusive concepts with apparently limited applicability. It's probably clear to most of us adults that sexual intercourse is pleasurable at times, and that a toothache is painful, but whether writing this book is pleasurable or painful I'd be at a loss to say. Furthermore, many writers have talked about the "paradoxes" of hedonism, e.g. that planning for pleasurable events often reduces their pleasure. Hume seems to have sensed these difficulties and used the concept of "utility" instead. The measure of the utility of an object is the degree to which the object facilitates one in the pursuit of his goals. This definition does two convenient things. It removes the necessity of trying to assess the degree of pleasure one has in attaining a goal, and it enables us to measure utility along some recognizable scale, such as a combination of money and probability. Thus we escape the awkward task of "interpersonal utilities," e.g. comparing my enjoyment of a good meal with your enjoyment of a sail on the bay. There are technical difficulties with even this money-probability measure, but these have been thoroughly studied and to some utilitarian planners, at least, satisfactory methods are emerging.

Furthermore, we avoid insidious comparisons of the different goals people pursue. Hume dramatizes this point in one of his dialogues where a traveler recounts his visit to a strange land in which one of the leading citizens has a homosexual affair, is married to his sister, has murdered one of his best friends, and yet is one of the most highly respected of the 
citizens. When the traveler's friend interrupts to ask whether this tale is not totally fantasy, the traveler replies that the land he "visited" is

none other than Greece and Rome in the classical period. Hume's point is that we can only question the utility of a goal relative to other goals, and not the moral worth of the goal itself.

Now we need to examine one of the really puzzling aspects of all utilitarian ethics; namely, where the center of value lies. If we say, as Bentham did, that pleasure is the driving force, what does it drive? Bentham says, "the individual." But who or what is the individual? Or, in Hume's case, who or what has goals?

I suppose that both Bentham and Hume would reply "the conscious ego," because, after all, it is the conscious ego which "has" experiences, and pleasure and pain are experiences. Whether conscious ego has a utility function is not so obvious. In any event, modern empiricists such as consumer surveyors and pollsters, also assume that conscious ego is the value center which tells them what product or politician it most prefers.

However, we have already seen in the last chapter that conscious ego is not the whole of the intellectual mind; it is that which unifies experience at a moment of time, but it is not clear why this quality should make it a center of value for the individual mind. But Kant goes even further and finds the center in a totally different part of the individual.

Before turning to Kant, I should discuss a far more sophisticated attempt to preserve Hume's idea by trying to define the center in terms of the potential behavioral properties of an individual. The theory states that what an individual wishes ("intends") in terms of goals can be ascertained by observing behavior and inferring potential behavior. The "individual" is a complex of potential behaviors individuated by space and time. The goal or goals an individual wants are those he would pursue if the had perfect knowledge and access to all potential goals (other stipulations need to be added, but these need not be detailed here). The point is that even though the "individual" is a complex of inner attitudes, categorie, or whatnot, his potential behavior is a result of all these. But this suggestion, appealing as it is to empirical investigators, doesn't necessarily solve the problem. Suppose the "inner" self of the 
individual is a battle between a number of forces, as Jung suggests. And suppose that maturation (or as Jung says, the process of individuation) is losing the battle. Then does it make sense to say that the "individual," who is really not an individual at all, truly wants what his potential behavior says he wants? "He doesn't know what's good for him," seems to make good sense for someone who has lost touch with his inner self. 4. Kant

Now let's see how Kant tried to frame the ethical issues of human life. It may help to turn back to Bentham's beginning and compare it with Kant's: "Nothing can possibly be conceived in the world, or even out of it, which can be called good without qualification, except a Good Will ... Power, riches, honor, even health, and the general well being and contentment with one's condition, which is called happiness, inspire pride, and often presumption, if there is not a good will to correct the influence of these on the mind, and with this to rectify the whole principle of acting, and adapt it to its end." (Foundations of the Metaphysics of Morals, First Section)

So close together in time is the writing of the two passages by Bentham and Kant that I can easily imagine a synchronicity such that the two authors penned them at the same moments of time, and that Bentham's unconscious was responding so vehemently to Kant's statements that he was driven to state so unequivocally that pleasure and pain are the only drivers of human beings, and that Kant was driven to make his strong remarks about the weaknesses of human happiness as a guide to the good life.

What does Kant mean by a Good Will? Since it is absolutely good, it does not operate by conditionals. "If you want to be happy, or healthy, you ought to do such-and-such" is a conditional. But the Good Will has only one principle, which is categorical. A friend of mine was thinking of using threatened electric shock in his experiments with human subjects. I advised him not to. "Why not?" he asked. "Because it would be immoral." This is the property of morality that Kant found appealing: there are no further arguments to be found other than an elaboration of meaning..

Kant's metaphysics led him to his formulation of morality. As we have seen, the first Critique dealt with the world of phenomena, i.e., intelligible 
experiences, but it left open the question of whether or not there are other worlds of "things-in-themselves," which he called noumena. If the Good will is such a being, it can have no relationship to experiential concepts. Thus, "thou shall go to mass each sunday, or thou shall eat only kosher food" are both too directly tied to the specifics of experience. Hence, the moral law must be as general (universal) as possible. The result is his categorical imperative, which I'11 translate somewhat. If on a street with heavy traffic you cut in ahead of another car, the driver may roar "What's the big idea?: If his question makes good sense to you, then it's easy to understand Kant's imperative. You are to imagine that every action you will to occur has a "big idea," i.e., a point to it, You are also to imagine that your will has universal legislative authority, so that you can will your "big idea" into a universal law, applicable to all other wills. This imagination places an extraordinary burden on your will; you have become king of the world! If you can tolerate the burden of having your big idea become a universal law, then your big idea and the action are moral. If you cannot, then the big idea and the action are immora1. Thus, if the big idea of cutting in on another driver is to shorten the time of travel, then you universal law says that all drivers must take any means available to shorten their trip home; I'11 leave it to your imagination to picture the resulting traffice scene.

As in the case of many philosophical systems, we can cut off Kant's metaphysical base and appreciate his idea on its own. What he has done is to elevate equity to the highest pinnacle of human values. Our morality is based, not on maximizing benefit minus cost in a community, but rather on making sure that no inequities occur, that everyone is treated fairly. Kant's way of putting this idea is again in the form of a moral maxim: each of us is to will his/her actions so as to treat humanity, either in ourselves or any other, always as an end-in-itself, never as a means only. This follows, he thinks, from the first maxim, because everyone is in principle a universal legislator who must on this account have equal importance with everyone else.

Kant's theory of morality is not egalitarian, i.e., does not necessarily say that all sha11 share equaliy in the world's resources. Rather, he emphasizes that moral equity implies that the will of every rational being is a universally legislative will. The ideal is a "kingdom of ends," in 
which in matters of moral duty, everyone legislates universally, everyone is king.

If we are to accept Kant's moral theory as part of the systems approach, then we arrive at another perspective of the basic questions of planning. In Kant's ideal, on matters of moral duty, the client, the decision maker and planner are one. The purposes and measure of performance disappear (there is no "tradeoff" for immoral acts). There are no components or environment. Implementation occurs immediately, as each wills the idea of his act to be a universal law. We could say that the Kantian social objective is that the planner and the decision maker wither away" in the moral domain: there is no need, in the ideal, for laws, or lawyers, no need to regulate. Of course, a new set of categories emerge. In place of a tradeoff principle, there is repentance and forgiveness, for example. If I will an immoral act, I cannot "pay" for it, but I can repent and pray for forgiveness.

But now we run into a difficulty: what does the phrase "in matters of moral duty" mean? Surely, the citizens of the kingdom of ends will not be deciding how strong the steel should be for a bridge, or the manner of operating on a cancer patient, or teaching mathematics. What is the boundary between the moral and the technical? Kant tried to help in this matter by distinguishing between different types of "imperatives." Hypothetical imperatives like "if $X$ is to occur, then do $Y$," may be technical and require the expert, e.g. if $X$ is building a bridge, curing a disease or teaching a course. On the other hand, if $X$ is a Benthamite "to be happy," then $Y$ may be a combination of expert and non-expert knowledge. When the imperative has no conditional, i.e., is categorical, then it is moral, and every will can decide.

On the matter of categories, we still have the question of the guarantor in Kants' moral theory.

But before considering the central role of the guarantor in Kant's philosophy, it is important to examine some of its inherent difficulties. It's very interesting to see how appealing, and even how glorious, both Bentham's and Kant's program are when viewed in the large, and how troublesome they both become for thought when considered in the specifics. It seems very noble to say that the prime objective of all legislation should 
be the greatest happiness for the greatest number; but when we consider the happiness of a specific individual, we have great difficulty in determining what is being happy and how happiness takes place.

Similarly, what more noble ambition could mankind have than to create a kingdom of ends, where each individual wills his acts so as to create equity for all, each willing the universal laws that hold for all?

But, though we may be able to discern why certain "big 1deas" cannot be universalized, it is very puzzling to determine which can. In the Foundations Kant gives examples of actions whose underlying "big ideas" cannot be universalized, e.g. suicide and lying. This seems to imply that we could will two universals: never take your own life and always utter the truth (at least as you understand it). Neither universal seems very palatable. If I am almost completely certain that I have a cancer which will soon turn me into a vegetable for a prolonged period of time, why shouldn't I set my affairs in order and commit suicide? Such an act, indeed, seems fully to treat humanity both in myself and in others as an end, whereas restraining from suicide seems more like treating my temporary living self as a means for pure survival, not to mention those who will have to care for me. Kant's logical mind responded to this argument as follows: "we see at once that a system of nature of which it could be a law to destroy life by means of the very feeling whose special nature it is to impel to the improvement of life would contradict itself ..." But the question is whether the life of one who faces non-human living would not be "improved" by the act of suicide. The point is not to bicker with Kant regarding his examples, but to show the extreme subtlety in trying to find principles which can be willed to be universal.

As for always telling the truth as we see it, God help us! Deception is an integral part of human living and communication, where truth often exists in the unconscious, and properly so. That most marvelous communication device called silence is a powerful way of not uttering the truthor anyting - in order to send a message. of course, our pragmatist will point out that lying or silence have pragmatic truth, since they serve well in attaining specific goals. But then the pragmatic maxim says "always speak or not speak-so that the right goals may be obtained," which is a very difficulty maxim to understand. 
It begins to appear that all the universalizeable maxims are not simple. To spell out the maxim concerning suicide or 1ying, we are forced rationally to consider again the whole system, its clients, its components, environment, etc. Consider another example, our relationship to other living species. The simple maxim would be "thou shalt not will the act of killing." But this seems a quite unnatural maxim for a species to follow with respect to all other species, assuming that predator-prey and food chains are biologically natural. On the other hand, wanton slaying of masses of living beings, leading to the extinction of a species, also appears unnatural. The maxim that emerges is "act with respect to other species so that your act is natural." But this is not a simple maxim; amont other things, human intelligence vastly obscures its meaning because it blots out any instinctual knowledge we might have that would aid usas it does other species-in obeying the maxim.

Now we can return to the matter of expert knowledge with respect to Kant's categorical imperative. Suppose, as he was designing the first assembly operation for the manufacture of automobiles, Henry Ford had asked "should I, morally, make cheap autos?" He might very well have replied "Yes, because I can easily will the law that all persons who desire it should have cheap automobile transportation; it is my contemporary auto makers who are immoral because they build cars only for the rich." A time traveler from 1977 would have been able to tell Henry that his "universal law" would eventually produce the smoggy cities of today. Hence, aren't experts really needed in Kant's word: systems planners who can trace out the consequences?

None of these difficulties with Kant's moral philosophy diminishes one bit its value and importance for planning. It is always relevant for the planner to ask whether a principle that is being used to evaluate a policy or action can be universalized. In one cost-benefit study for a new London airport, the planners estimated the cost of the possible distruction of an old Normal church in terms of its extant fire insurance; the universal maxim becomes: "the monetary value of anything is the price that would be paid were it to be destroyed." This would put a lot of us who fail to carry insurance into the category of complete unimportance relative to social changes. Another government C-B study used "expected 
future income flow" as a measure of human value, thereby condemning old age programs to a very minus benefit-minus-cost. In all these cases, it is the failure ot be "universal" with respect to all humans that leads to immoral policies which nevertheless satisfy a total costbenefit criterion.

It is absolutely essential for the health of our species, I think that we use "moral assessment" as well as economic assessment. We may judge that we should adopt a policy when we also judge that the underlying principle cannot be universalized, just as we often judge that the policy may not be economically sound. But we should bring up to our collective consciousness the inherent immorality of our policies.

We find difficulties similar to the ones above if we turn to Kant's other version of the moral law, to treat humanity never as a means only. How are we to understand this principle? One likely guide is to say that if in our planning we treat people the same way we treat machines or rocks, then we are treating their humanity as a means only. But this is much too strong. On an individual level, we all treat postmen, ticket takers, policemen; soldiers, as means only, in the sense that were they automated, we'd not recognize the difference, except perhaps to worry about their unemployment. Even teachers are treated as means only; in some coming age, there may be public computers which answer such questions as "tell me all the books and articles that have been written on the systems approach." Indeed, the computer would be better because I tend to reply "uh-that's a tall order," whereas the computer would bury him with data!

And what is the word "humanity" supposed to mean? Kant himself was aware of the danger that his maxim might be interpreted in a purely negative way, with its ominous "never." One way to handle the maxim might be to gather together your resources and retire to the wilderness to become a hermit. Then the only way to break the moral law would be to treat your own humanity as a means only. But, Kant says "it is not enough that the action avoids treating humanity - as an end in itself, it must a1so harmonize with it." He goes on to say that "humanity" is something which has degrees of perfection and the maxim implies, not mere avoidance of treating humanity as a means only, but the obligation for advancing humanity on the scale of perfection. One can recognize how rich a meaning Kant was 
able to squeeze out of his rather sterile, logical categorical imperative. But here again we see the need for the "expert" on human development to guide us in the improvement of the human species.

The idea of harmony takes us back to the guarantor. But a few concluding remarks on the difficulties are in order. First, there is no question that the general idea of Kant's "humanity principle" is very rich, both as a planning guide and basic human policy. It was an eighteenth century dream of total human equity, regardless of race, age, status, whatever. Its ideal was to remove in human societies all hierarchies based on empirical criteria such as power and wealth.

Second, Kant himself recognized the difficulties of ultimately justifying the rationality of his moral law. The Foundations ends: "thus, while we don't comprehend the practical unconditional necessity of the morai law, nevertheless we do comprehend its incomprehensibility, and this is all that can reasonably be required of a philosophy that struggles to carry its principles up to the very limit of human reason."

6. The Guarantor

We have seen how, for Kant, there are two basic values of the human being, happiness and the moral law. One cannot act to achieve happiness and thereby be moral, for morality demands that the moral law be the sole motive. Does the reverse hold? Can one achieve happiness by acting morally? The answer is "apparently not," since virtuous actions so often lead to unhappiness. But in principle there is no reason why this should not happen, for we can surely imagine a world, a kingdom of ends, where morality and happiness are in complete accord. Kant calls this vision the summum bonum.

But it is unattainable, for Kant. It can only make sense, therefore, if we humans can gradually approximate it. What are the necessary conditions for the reality of this constant struggle? They are Kant's famous trilogy: God, Freedom and Immortality. Only a supreme being could guarantee the reality of the endless pursuit; only if the will is free could the "pursuit" be possible; only if the soul (will) is immortal could the pursuit exist for each will.

History did not leave matters as Kant describes them. To be sure, the immortality of the social system seems essential if besides goals and ends, there are also ideals which can be approximated more and more closely but never attained. And to be sure, if this ideal seeking is to have sense 
as a human pursuit, there needs to be freedom of choice at the individual level. And finally, as we have seen in the last chapter, a systems approach which includes idealism as part of its rationality, must also assume a guarantor.

This historical review describes the background of the distinctions made in the Introduction. Bentham's approach sets the foundations of the socioeconomic assessment, and can be called an ethical approach to evaluation. Kant's approach sets the foundation of what we called the "value distribution" assessment, which, using his own term, can be called the moral approach. All planning for development should include both, and attempt to design social systems so as to minimize the conflict between them. 


\section{ŜECTION THREE: THE VANISHING COMMUNITY}

The third part of this interim report considers the hypothesis that rapid technological development in an area has often resulted in the destruction of the local community - so often that appropriate planning needs to examine in each instance the possibility that this "impact" may occur and to determine how to avoid it..$^{1-15}$ In this third section we begin to present evidence of different ways communities deal with development. In the fourth section, we consider the specific case of Lake County. One highly visible artifact of rapid development is the boom town. Because of the extremes found in boom towns, they serve as very good sources for study of the interface between communities and large-scale developments. Boom towns are historically well known in many parts of the United States; a number of their living descendants or ruins lay scattered across the western landscape from the days of gold, cattle, silver, oil and land booms. Some of these boom towns have survived as communities and continued to grow while the others have become ghost towns or, at best, marginal places to live and work.

The newest population of boom towns have been spawned by activities brought about by the energy crisis. A resource-hungry nation has turned to this region for development of its abundant resources. ${ }^{16-33}$ Boom towns have been described in a variety of ways, each with the person's own emphasis on certain aspects of the phenomenon. The usual method is to identify a certain rate of population growth over a period of time. (According to John S. Gilmore at the University of Denver Research Institute, most boom town effects begin when growth rate exceeds 15 percent.)

Associated with this growth rate are a number of symptoms and syndromes related to community health and stress that are used as measurements of the effects of such growth.

The aspects of boom town development are felt both by the newcomers and old-timers in areas such as: (1) lack of adequate housing; (2) 1ack of entertainment and recreational facilities; (3) poor or overcrowded school facilities; (4) lack of paved streets and roads; (5) high prices and cost of living; (6) inadequate medical facilities; (7) poor quality 
shopping facilities; (8) limited social and municipal services; and (9) traffic congestion. These negative realities are very straightforward and easily recognized.

Not so easily recognized and mitigated are the rising incidences of: divorce, crime, drug use, child abuse, suicide, alchoholism and similar symptoms of a severely stressed social system. There is good reason to suspect that less visible long-term damage to individuals and social systems are a result of the boom development as well.

Pre-boom residents will also be more acutely aware of such losses as: loss of air and water quality, crowding and congestion, deterioration of the natural environment, the loss of hunting and fishing as the capacity to sustain yields is reduced, loss of control over local affairs, inability to keep up with high income newcomers in competition for such basic needs as land and housing, alienation from sense of community. The local population is overwhelmed by outsiders who have limited commitment to the community and location, loss of a way of life, loss of quality of life. The number of negative, non-quantifiable aspects that affect the original residents of course is much larger, and much is still hidden; but the above list serves as a sufficient example of the complexity of determining the costs of development in other than purely economic terms.

There are a number of benefits that come with development if properly planned for. The obvious benefits are the satisfaction of a market demand such as energy and the chance for careers and jobs to develop around the resource or product. In many cases, development occurs in economically depressed areas. The development can create the groundwork for independence and prosperity for people who would not otherwise have that option, as is the case for the American Indian's relationship to coal development. These benefits are not automatic, however, and must be carefully planned for and implemented through deliberate policy decisions. There is also the problem of the distribution of benefits and costs which must be taken into account. Benefits are promised, for instance, to the parochial population in the immediate vicinity of a proposed development. In an overwhelming number of cases, it turns out that these benefits may not materialize. 34 Skilled jobs go to outsiders with no hope of locals receiving training, the construction periods are short and intense with little promise of 
economic stability, tax monies disappear in the rising costs of running governments serving more people and the resource itself depletes within a generation.

Growing resistance to development comes from the memories of historic developments of the scale and intensity that boom towns associate themselves with, of the unfair share of costs born by those communities and their descendants, and of the lack of a fair share of the benefits. The memory is in fact so strong with many communities that the hope and promise of development no longer seems to hold any validity. Development is perceived by many of the residents to be entirely destructive to their own way of life which is seen to be a manifestation of a unique and highly desirable "quality of 1ife." "Quality of life" is a recurring phrase in interviews and writings of residents of would-be boom areas that seem to embrace the ultimate measurement of whether the change brought about by development is an improvement or degradation of life, a benefit or a cost.

Another very important consideration associated with the distribution of costs and benefits is the intensity and scale of the development. For instance a benefit can lose its relative value if the development occurs too quickly or too obtrusively. Stress caused by change can be a benefit if it does not become oppressive. Careful study is needed to understand when stress to a community from development becomes oppressive rather than beneficial.

Study of various boom town or boom town-1ike developments reveals that boom towns are an artifact of a more generic, less site- or resourcespecific problem of the way growth and change stress social systems. It is a problem related to mankind's approach to the planning and implementation of deliberate change. At the end of this section are excerpts from recent newspapers and magazine articles that reveal the universal nature of the conflict between the costs of development and "quality of life."

A great deal can be learned from the way these other communities from around the world individually face the problem of distributing the benefits of development and enhancement or loss of their "Quality of Life."

In the West where the dominant artifact of the energy resource development is boom towns, a number of communities suffer the stress and consequences 
of a boom-like development without the clear, distinct activity associated with the boom towns of the Rocky Mountain States and Alaska. Even apparently dissimilar areas like suburbs, urban neighborhoods and bedroom communities feel the anxieties and stress of a lost quality of life.

An emergent pattern of reaction by communities faced with development is the division between two kinds of citizen. There are those who are convinced of the benefits of development whether because of immediate payments through royalties and similar payments to the owners of the resource or through the prospect of new jobs, increased economic stability and tax incomes or those who believe that development is essential for the good of society. There are those citizens, on the other hand, who are convinced of the detrimental effects of the development on their quality of life. As the debate rages, fueled by the developers, special interest groups and governmental agencies, the residents are driven further and further into their corners with less and less chance for reconciliation. The issue is usually resolved by governmental intervention, judicial judgment or by the community becoming completely overwhelmed by the economic realities of a resource-hungry world.

The lion's share of attention in these issues of development at the scale so apparently integral to energy resource development has dealt with the effects of development on the natural environment. Special interest groups representing environmental issues have expended a great deal of time, money and effort countering development interests through lobbying activities in legislative halls, through court actions and through educational efforts aimed at the general public. On their own behalf, development interests have countered with similar efforts pushing their own world view of the cosmology of man. Governmental agencies for their part pursue the missions with which they have been charged, which reflect the policies of the political decision makers.

Attempts to legislate sensitivity to environmental concerns during development efforts such as NEPA (National Environmental Protection Act) and CEQA (California Environmental Quality ACt) are examples of reactions to past developments that resulted in major environmental degradation. 
This kind of legislative intervention into the development process coupled with a growing negative view of any kind of development by a large portion of the public has increased the time and cost of doing business in the energy resource development area, despite the fact that the energy crisis created the demand for more development.

The actions and reactions to the pressures for development (development that has led to consequences like boom towns) has been centered primarily around the resource or the technology whose utilization is under consideration. Methods of measurement used in EIR's and EIS's (environmental impact reports and environmental impact statements) or similar assessment methods like cost-benefit studies, have been predominantly based on quantitative indicators. Socioeconomic assessments have largely been economic with some statistical information on social patterns included. ${ }^{35-38}$ In short, the very central and pressing issue of the endangered quality of life as the community members see it has not been dealt with consistently. This is due to a variety of causes with the frighteningly consistent results: the complete and irreversible loss of quality of life for that unique group of people-in many cases, the loss of their way of life, culture and tradition. The vanishing community. The cost to the community includes not being able to adapt to the change brought by development on their own terms. The essence of quality of life remains uncaptured by statistics on housing starts, visitor days, child abuse or megawatts of domestic energy.

A number of communities experiencing boom town development have been or are being studied with mixed results. In Rocksprings, Wyoming, a local official said the next person carrying a clipboard and asking questions was in danger of being shot. The not so subtle message was that the entire research effort, as extensive as it was, did nothing to alleviate the very serious and destructive problems facing the town." Some towns like Coal Strip, Montana, have experienced the boom and have been left to recover and wait for the next. The experiences of towns like these two have shown that even the so-called outsiders can suffer loss from poorly distributed benefits and costs. Unions are unable to attract or hold workers and the quality of work life is definitely a growing concern of the union leaders. Industry and government agencies are all 
hurt by the growing costs of mitigating damaged communities and environments.

There is growing concern over the need for planning. The questions are who should plan for whom and what kind of planning should be done and how should it be implemented? How should one plan for, protect and enhance the "quality of life" in a community? How can the trend of the vanishing community, lost lifestyles and cultures be stopped without freezing them in a zoo-1ike existence; too precious to experience any change at all.

Jouni Labba presides over a land majestic in its simplicity. Hills, lakes and birch-studded tundra sweep north to the Arctic waters beyond the horizon. The sun dazzles the melting patches of snow and the silence is punctuated by the bells clunking from leather collars of his foraging reindeer.

The land belongs to Labba, though he does not own it. The tousled blond, reindeer herder is one of the Saame people, better known as Lapps, who have lived for centureis on the gragile nature above the Arctic Circle.

But the timelessness has given way to technology and tourism, bringing changes that have put new stresses on the once free-wheeling Saame people. 'Earlier the pressure was not so much, said the 31 -year old Labba. There were fewer tourists. But now the pressure is harder. And to keep our way of life, we have to become more militant.'

"Closing in on the Lapps"

Christopher S. Wren The New York Times June 12,1977

Thousands of Indians are trying to stop construction of a gas pipeline along the mighty Mackenzie River in Northwestern Canada. They fear it will destroy their traditional way of life $\ldots$

Mr. Erasmus, whose organization claims to represent about 7,000 Indians, said the piepline and its associated industries would require highly skilled labor and thus would not benefit the Indian.

'But it will destroy our traditional way of living off the land,' he said ...

Canadian Indians Oppose Mackenzie Valley Pipeline

James Foley The Christian Science Monitor July 6, 1977 
Concern is growing among the people of Stravanger and other small communities scattered along Norway's west coast about the ravages that oil may bring.

Apart from ecological considerations, highlighted by the blowout of the Bravo oil rig which poured millions of gallons of oil into the ocean, people see a threat to long-established beliefs and customs in effect, a whole way of life.

The 100,000 or so people who live in those west coast fjord towns and communities are deeply religious, committed church goers with strong links to their forefathers and thier old crafts and trades. Much of the work in the area is based on fishing and farming.

EROSION EMERGES

But the oil boom, which began here five years ago, has begun to eat away at the core of fundamentalism which has always sustained the people here ...

Signs of the changing social patterns are already evident.

Norway's Life-Style Resists Oil

Vincent Boist

The Christian Science Monitor

May 10, 1977

Sitting in the cool of the abai, the men's meeting house, I listened to the village leaders express thier opoosition to the oil super port proposed for their island home, the Micronesian archipelago of Palav (see Sierra Club Bulletin, June 1976). Outside, thenoonday balzed down on coconut palms and papaya trees and glistened off turquoise water rippling over some of the world's most productive coral reefs.

Here on the island of Kayangel, near one of the possible super prot sites, these men, fishermen all, know first hand about oil pollution. They still point to the small Okinawan tanker that ran aground years ago, its rusting hulk resting on a dead reef.

But as one elder said, 'Oil is not the only pollution we must worry about; Western culture will destroy us ...'

The Perils of Palav

Marry Ann Eriksen Sierra Club Bulletin May 1977 
Conneaut, Ohio

This town of 15,000 on the shores of Lake Erie near the Pennsylvania border has not changed very much in the last 50 years. It might change a lot in the next half century, however.

The shadow of $\$ 3.2$ billion hangs over Conneaut (pronounced Can'-ee-aht) in the form of a proposed giant steel plant which U.S. Steel may construct here. Population could double in the next five years and reach 100,000 by the turn of the century.

BRIGHT PROSPECTS

Conneaut faces a question common to many U.S. towns and cities: how to cope with economic growth without destroying the quality of life, the community treasures.

"Huge Plant Ahead for a Little Town?" John D. Moorhead The Christian Science Monitor March 18, 1977 
SECTION FOUR: CASE STUDY OF PRE-DEVELOPMENT PLANNING-LAKE COUNTY

The recent statement by President Carter asserting that the present energy crisis was the moral equivalent of war has heightened the intensity and drama associated with the geothermal development of areas like Lake County. In war, casualties are expected and can only be minimized. Shortcuts are taken and fairness and equity are held in reserve for the reconstruction period when peace has been once again established. Nobody talks about the fairness of war. It would seem then that our attempt to make an appraisal of the distribution of benefits and losses due to the energy resource development in Lake County is ill-timed.

It is the thesis of this study, however, that even for the apparent immediacy of the present crisis, there are a number of very compelling reasons for making such an assessment now.

One such reason has been developed in the third section of this report, called the "vanishing community." Lake County may not be another example of this type of historical problem, but at the present time there is no sure evidence that its communities will share equitably in the costs and benefits of development. Even with all the hoped for improvements that seem possible if development occurs, there is that apprehension among some of the residents that something may go wrong, that the children and grandchildren of today's residents may have to pay too high a cost for today's benefits. Yet there is the hope that economic boons will provide for a better future for these coming generations. There is hope that the quality of life in this community can be protected, nourished and improved if development is done thoughtfully. Until this anxiety and hope is resolved, the development of geothermal energy in Lake County will continue to be impeded by citizen reaction. Resolution will be the first step towards a sense of community trust that in turn will reduce the need for the ever-growing piles of regulations and restrictions that are now the community's fragile defense line.

Lake County, California, is as typical as it is different from other rural areas in the United States that are feeling the quickened pace of 
growth and change. These communities are traditionally ill-equipped to deal with the pace of this change and the direction that it is taking them. Fear and anxiety mixed with excitement develop within the community over what the future holds for them and their children. Some of the voices of enthusiasm and concern are appended to this section.

The problem from the communities' point of view is how best to survive the dramatic changes in their lifestyle and physical environment and, if possible, secure an improvement in their quality of life. The growth pressure being felt by Lake County at the present is part of a nationwide trend of population movement back to the rural areas of the nation. 39 This population shift has been attributed to a number of causes: industrial relocation, preferred lifestyle, retirement and resource development. Lake County would have problems of growth and change even if there were no geothermal resource. Although planning as a concept is new and not always welcome in areas like Lake County, there seems to be little doubt about whether planning will take place: the question is what kind, when, how and by whom?

Coal development, railroads, land speculation and gold mining are just a few activities of the not-so-distant past that made very large and irreversible impacts on the land and communities in the vicinity of the activities. The price of not reflecting on such activities is still being paid by the land and the descendants. 40-41 Such past indiscretions have accumulated as a residual memory in the minds of the residents and friends of today's rural communities. The mistrust and fear of paying too much for the promised benefits have caused an exponential growth in regulations and controls aimed at reducing the possibility of repeated negative impacts from growth and development. They are intended as insurance against even worse things occurring.

How should planners and decision makers, whose charge it is to protect and enhance people's lives under their public reponsibility, respond to the challenge of a growing appreciation for the extreme complexity of the planning problems that they face? 42,43

A good first approximation might be to attempt to recenter the problem. An image of the importance of this first approximation can be borrowed from the craft of the potter. The creation of a piece of pottery 
starts with the process of centering the clay on the whirling potter's wheel. Any good potter understands the importance of this first act as it relates to all other steps leading to the completed product. Any attempt to pass quickly over this important step in a rush to the more dramatic act of shaping the form and firing the glazed clay body reduces the quality and substance of the finished piece. The memory of any loss of concentration and effort at this very first step is carried through the entire process in the form of imbalance. The piece is too weak in some places, too heavy in others and lacks the elegance of form. In many cases the piece will destroy itself as it spins on the wheel while the potter attempts to develop its initial form. The weakness and heaviness under the test of centrifugal force are too great. Even if the piece is cajoled into remaining intact, the process of firing the clay body into rock proves to be too much stress, and the piece deforms and is retrieved from the cooled kiln as a disfigured parody of the potter's intent.

Centering the intent of a planning effort requires the same concentration and completeness as imaged in the above example. But just as the potter must decide on what constitutes a center, so must the planner or problem solver, and an inadequate decision in both cases ruins the whole. Historically planning has been erroneously centered exclusively (we think) around technologies and resources so that the whole planning effort has been flawed relative to social well-being. A better place to start the process of centering is to shift the planner's and decision maker's efforts to the development and protection of community and make that process the focus or client of the planning effort. This will pull in humanistic information to complement the technical information. The important difference between this focus and the historical approach is the number of new sources of data and information that become relevant to the planning process which have not previously been considered. The decision maker or planner is also able to use existing data in a more directed way. One new source is the value expert. An important change comes with a revised concept of what is meant by data and information as seen by a value expert.

Data are part of a chain made up of different conceptions of knowing. The nature and validity of data are directly related to information, 
knowledge and wisdom. Under the influence of the issues that communities in Lake County face, data becomes information only in the presence of wisdom. It is unlikely that traditional engineering-science types of data will result in "wise" information when used alone. The scientist can and has in the past used the scientific method to solve many different kinds of problems. In fact, the success of scientists in the past has been so phenomenal that they have been asked today to do much more than is possible.

Companions to the scientific experts are the professional experts who operate by depending on a consensus of peer opinion to determine the validity of knowledge and data. Any conflicts in the process of problem-solving by either scientists or professional experts are resolved by making expert or professional judgments. Although this effort has proven technically proficient, it has been inadequate when faced by issues similar to the Lake County geothermal resource development effort.

The recentered effort reveals the need for another kind of "expert," this one not an outside professional, but someone within the community, the value expert. In whatever way this expert operates, it is through his/her wisdom that the search for data and information can be validated. Without this very important resource, any efforts at developing so-called baseline data will end in a great deal of frustration and wasted effort. This can occur with even the very best and most enlightened effort. An example of this can be found in the results of a recent research effort conducted in Canada related to the proposed routing of a gas pipeline from northern Canada to the United States. This study, known as the Burger Commission study, spent two years collecting "baseline" data, using a very sensitive and enlightened methodology. The group flew into every Indian and Eskimo settlement and village along the proposed route to collect the most complete cultural, social and anthropological data in the history of these natives. Frustration arises because these data do not solve the issue of what ought to be done in planning terms. Despite the large amount of social data that was collected, the investigators failed to determine who were the "value experts" in the community and the relevant information they could contribute. It seems to us reasonable to say that the native groups are among the prime clients and therefore 
wisdom about their values is essential in development planning; this wisdom can only be found through the community's value experts. It is this wisdom that reveals what is a benefit or cost, what is important and what is an improvement or gain in quality of life.

In other words, the Burger Commission expanded a badly centered planning effort and has not solved the development problem. It has only served by its effort to reveal a very critical aspect of the endeavor. Without this aspect; namely, the determination of community value, the task of collecting baseline data or any other kind of information becomes cynical in nature. To use Oscar Wilde's definition of a cynic: "A cynic is someone who knows the price of everything and the value of nothing." Cynicism is destructive because it destroys the vision within the community, and the planner and the decision maker. Vision, as it turns out, is the essence of the judgments of the value expert. The value expert in the community is an expert because he/she has a vision of the future of the community. Helping to uncover and enhance this vision is an important task for planners and decision makers to become involved in.

Now let us turn to lake County. There are a great many "value experts" (who are seen as clients of the planning effort) in the county. Some represent local interests but also make their demands felt at the state and national levels. Their own needs and desires place pressure on recreation areas, wilderness, wildlife, strip mines, pipelines, offshore drilling, food, transportation and a variety of other demands that cause other communities to seek development and change. Therefore, there is an aspect of tradeoffs when talking about benefits and costs from the community's viewpoint.

There are a number of other possible client taxonomies that are revealed when looking for value experts in a community. If an individual is understood to be one, then the process of growth, opportunity and fulfillment can be seen as modulators of development benefits. The family may be viewed as a primary client group as can fraternal, religious or political groups all with the concept of who is losing or gaining by development. The effects of special interest groups can be examined under site-specific conditions on the way these different client groups perceive the benefit or loss from change with an understanding of the applicability of these observations to other communities with similar generic issues. 
In a region like Lake County there is not a clear distinction of what communities are there or who is and who is not a part of a community. There is little evidence of a homogeneous population and as time passes and more people move in, each community's profile becomes even more obscure. The original inhabitants, of course, are hardly visible at all. The Indian culture and history have little influence in the county except in place names and museum exhibits. The Indians themselves are few in number. Many descendants of the first whites who settled on ranches or farms live in the county today. Their cultural imprint is somewhat visible, but they are becoming a smaller and smaller proportional group as the population increases. There are fairly recent arrivals in the country who have a full-time commitment to the country as a place providing jobs and amenities that make up a special lifestyle for them. There are people who live in the county part-time and who own land in other areas where they make their living and spend most of their time but nevertheless feel an attachment for Lake County as a place to retire or to visit for recreational purposes. There are the people looking for recreation on or near the lake who return to the lake year after year or they are the retired who have come to Lake County for the low taxes and the rural atmosphere that is complementary to a reduced pace of life. There are people looking for altemate lifestyles that depend on a certain amount of isolation from other people and who desire the same kind of rural atmosphere that is considered by many to be one of the qualities of life that people refer to so often. There are ethnic groups, i.e., the Spanish Americans, who were attracted by the agricultural industry originally and who still retain much of their cultural heritage.

Through all these groups and the many others not mentioned, there is the common thread of the historic events unique to Lake County. This makes Lake County very different from the many other communities that are going through intense growing pains which have a much different community profile. The Norwegians face the influx of money and growth from offshore oil; the Eskimo in Alaska deals with offshore oil, money and pipelines; the Indians in Montana with strippable coal under reservation lands; ranchers and ranching communities face uranium mines, oil shale and power plants. Al1 of these community groups have a unique community structure, common culture and values specific to their history and place. What is 
Lake County's profile?. That is an important question to be answered in future research.

Other client groups are represented implicitly by the different agencies that operate in the Lake County area. These clients are represented by group values on a state, regional or nationwide scale. The Forest Service serves a national client group that demands forest recreation, conservation and timber. The National Fish and Wildlife Service serves those who value the recreational and aesthetic values of their charge, including the rights of the fish and animals themselves. The state has similar agencies that deal with similar client groups but that are related more to perceived state needs. There are federal and state agencies dealing with specialized needs of client groups as represented by ERDA and the Energy Commission. This list of such agencies and their implicit or explicit groups is very large and difficult to comprehend even in an holistic framework (see Section Seven).

There are also industrial or commercial groups that serve another group of clients and their perceived needs and wants. In a certain sense they are their own client and serve their own needs as well as a market demand for their product. These clients include those who demand only the highest return on a venture and are not tied to the product or process. As an example, the geothermal industry is made up of engineers and managers who have specialized in energy resource development, and it is an integral part of their way of life. The energy users in the Bay Area, as another example, depend on an energy supply, not for just air conditioning and heated pools, but for their jobs (most critically those of the low income groups). There is the client group that provides the risk capital and operating capital who have an excess in their income which they would like to invest in any venture that has a balance between risk and return. Their willingness to participate in something like geothermal development is based on their demands being met.

Another group representing client groups outside the physical boundaries of Lake County are special interest groups made up of private citizens rallied around some common cause such as that represented by the Audubon Society, Friends of the Earth and Sierra Club. These groups represent clients with values and perceptions of Lake County that are growing in prominence. 
In addition to all these client groups that are relatively easy to identify are social and business groups represented through localized membership tied to state and national groups. These include labor unions, service groups like the Lions Club, and groups like the $4-\mathrm{H}$ Clubs.

Not to be left out as a represented client group are the future generations and the young who are now effectively outside the decision-making process but who will soon inherit their parent's world. For them the question is what kind of a world would they want to receive?

All of these client groups are very much concerned with the future of Lake County. For the planners (many or most of whom are members of the client groups), the issue is one initially of trying to comprehend the relationships between these groups, how the perceptions and values of each can relate to the others, and how one can equitably determine a fair distribution of benefits and losses and to insure that the losses do not overwhelm or overburden any one group.

Within each of the groups mentioned above are to be found what we have called the "value experts." It is apparent to the research team that a reasonable first step would be to call these "value experts" together in some type of planning workshop. In what follows, we try to concern ourselves with guidelines and precautions in the conduct of this first activity and subsequent planning strategy.

A priority task for this meeting is to develop ways the experts can express values. The diversity of the groups and the many conflicting world views require an understanding of the difference between ideals, objectives and goals. Goals are ends that are short term, objectives are medium term, and ideals are very long term.

It may happen that one value expert concentrates on goals (e.g. rapid geothermal development) whereas another is thinking in terms of ideals (Lake County as a "perfect" place to live). The dispute between these two experts may be frustrating because they are on different planes. The workshop should be designed so that this frustration can be eliminated: does the goal of rapid development lead to or away from the ideal? Do they agree on the ideal and differ on the appropriate pathway?

Another confusing difference among the experts is their general "managerial attitude." Russe11 Ackoff sees four such attitutdes: 
(1) survive in an environment as it is (2) wait and see-crisis orientation, (3) predict-and-prepare and (4) "make-it-happen." We may expect to find this variety among the experts.

Something that must be considered when talking about planners and decision makers is that the design of the planner and decision maker is as important, if not more so, as the formal methods that are espoused. The so-called methods and techniques are the very rational and explicit ways that planning is supposed to take place. It seems unrealistic to depend on them as guidelines, however. Decisions are made within the planner and decision maker that in fact may have little or nothing to do with formalized planning efforts and management techniques. Politics, power, intuition or any of a number of hidden reasons may guide these people. For this reason it is very important to carefully look at the archetype that fills the planner and decision maker positions. As in the process of imaging idea1s, it is very important to include all types of people in the planning-decision-making process.

The use of a variety of people in such important roles in the planning process helps the implementation of any goal-directed action by increasing the variety and complexity of such actions. Without the much needed guarantor of our planning activities, this effort helps to identify the common values and protect the system from developing into a monoresponse with too many critical links that can be too easily disrupted.

For the planning effort to secure improvement in the client social system, it appears that three sources of knowledge must be tapped: the scientific expert, the professional expert and the value expert. As in the decision to make the community the primary client as part of a first approximation, so too does the community become a primary source to look to for the value experts. In very superficial ways this source has been tapped by a variety of methods commonly listed under the general heading of "public involvement." In an effort to improve on these efforts, some basic a priori assumptions must be discussed. First, the pub1ic or community or "the people" cannot be viewed as a static component in a dynamic system. Second, it is of little use to either the people who are the planner's clients or the planner to hold the typically maudlin view of the social system that is so common to efforts aimed at including people in historically isolated planning and decision-making efforts. 
The required task is to accept the complexity and contradition of the client group as a reality in an already complex and difficult planning problem. Finally, to be able to search out the information to be gained from the value experts and to be able to use that information in implementing a plan of action, two important time-based functions have to be facilitated by the designers of the workshop and subsequent planners. There has to be a process of "warming up" to the subject. The outside planners and decision makers spend great amounts of time and effort learning their ski1ls and developing their perspectives of what needs to be done and how. It is seldom the case that the communities get the same chance. It would be a mistake simply to query the experts in somewhat the same way a computer data bank is tapped because the expert, unlike the data bank, is not "loaded" with the necessary information. This approach not only eliminates the process of discovery of values and perceptions over time, but almost guarantees the polarization and conflict within the communities. A tremendous effort is required to sort out ideals, goals and objectives. The task then is to ensure that the experts are given every chance to work through this warming up period to give the best possible environment for the development and input of values.

A very important part of the warming up process is the development of a visual perception of what the different goals and objectives imply. These visual perceptions and associated data and information on the consequences of different strategies serve to develop the vision of what can be considered a loss or benefit due to different changes from the value expert's point of view.

The drama of a community warming up to a change was recently played out very successfully in northern California. The reason for the change sprang from the aesthetic spirit of an artist in this case rather than the more familiar reason for change: crisis. The vision came from outside the community through a young artist who wanted to build a great white cloth fence running for miles across farmland and oak hills to end in the Pacific ocean. The nature of the concept dictated that every landowner along the proposed route give permission for the fence to run across his property. Everyone had to agree as there could be no breaks without a loss of conceptual strength. The saga of the artist, sharing 
his vision with these rural communities, helping them image and understand the proposed change was carefully watched. The range of attitudes toward the fence ran all the way from intense hostility to excited expectation. Through the warming up process, carefully tended by the artist, agreement by all the landowners except one was finally achieved and the fence was built... Trust was never broken between the artists and the residents. The change in the residents was dramatic. Their attitudes and conversations were filled with the excitement of having been a part of an aesthetic experience that was quite beyond their normal range of experience. Their participation was complete, down to actually inheriting the fence components after they were disassembled. All indications are that the residents felt changes in a very important, positive way by this participation in an act of being part of a work of art. The whole process is important not only in being an example of the warming up of a community to a change but has a lot to say about the aesthetic world view being the major source of change rather than a continual crisis motivation. The lesson of this story is that the workshop should be conceived as an initiation of a community process, rather than a "one-shot" confrontation.

The implication for the planner and decision maker is that there must be a new understanding of how change is conceived and implemented. Arnold $J$. Toynbee said in his Study of History that facing change is not a return to the good old days (archaism), not rendered in an ideal future (futurism) and not a realistic saving of the present situation. Successful change and improvement come through rebirth. The planner must be able to help facilitate the development of a vision within the value experts of a community, but the task remains to midwife at the rebirth and to assure that grieving for the way things were is complete and sufficient. This required task of the planner has tremendous implications for the question of who the planners and the decision makers ought to be. They, of course, must be aware of the importance of the above task.

A sensitivity to an issue like the need for a time to grieve over a change comes from planners and decision makers who are grounded in the methodology of a rational planning world view but who are equally aware of the validity and reality of other world views of planning. Planning acts can arise from moral, religious, political or aesthetic feelings and still serve the basic planning goal we assumed at the very. 
beginning; 44 that is, to secure improvment in the humand condition. Motivation for acts that do not necessarily come from acceptance of this assumption must a1so be acknowledged and dealt with to insure a truly holistic approach to planning. This is the reason that the client social system must be seen as a complex contradictory system. The public may include counterproductive elements that must be understood as a part of the value experts' input as well.

There are, of course, value experts from outside of the defined community boundaries that should have input for a variety of reasons or validations. Part of the planner's and decision maker's tasks include locating and including these inputs as we11. As stated previously, the planners and decision makers may come from within the community as well. as represent outside interests. They will all face similar general problems whatever their position.

An holistic and systemic approach to the overwhelming planning issues as exemplified in the geothermal resource development of Lake County has been shown to be a very good way to make a beginning in the assumed task of securing improvement. Despite the advantages of this world view, there is ultimately no guarantee that all the decisions and acts will be the correct ones. Once a plan is being implemented, ways of testing for satisfactory results and means of changing direction must be operational. The historical reasons for believing in the correctness of an action range from the theologic to the computer printout. In the present age little of the theologic is acceptable as a source guaranteeing the success and correctness of our planning activities. The sources that have been substituted have proven to be even less satisfactory. Anyone seriously involved in the planning effort must confront the problem of not leaving the client worse off than before.

The number of tasks continue to grow as our own warming up process continues. Although there are many more questions than answers at this point, and it seems that the process of warming up guarantees this will continue to be the case, there are many very important actions that can be taken now that will aid in asking the right questions and getting good answers to those questions. This starts with centering the planning effort around communities and community development rather than issues of technology and resources. It includes trying to answer the nine questions 
related to the client, planner and decision maker taxonomy of the systems approach. 45,46 It includes developing methods of assessing communities as the primary clients. What makes up a healthy community that can deal with change and take advantage of opportunities afforded by change? What is meant by quality of life, culture and values? How are the value experts to be found and utilized? What kinds of planners and decision makers are needed to deal with the complexity of the client social system? Methods of conceptualizing futures and dealing with the sense of loss and the ability to grow with the new opportunties are all requirements of skill for the planners and decision makers. All of these tasks must be started now if the historical cycle of damaged or destroyed commities is not to be repeated with our latest response to crisis:

the headlong development of energy resources.

... If this county has the geothermal resource that many people think it has, then it is possible that full geothermal development could wreck the county ... GRIPS* is needed to head off the problem that geothermal development could cause ...

Mary Hanchett Waterman
(quoting Larry Vollintine,
Lake County Planning Dept.)
"Millions Spent on Geo
Studies in Lake Sonoma"
Clear Lake Observer
Apri1 14, 1977

... Al1 systems go for geothermal energy!

George Malsbary
"Letters"
Lake Sun
July 19,1977

... Lake County is 'an ideal environment,' and our association is dedicated to preserving these natural attributes which make the county an agricultural and recreational center in Northern California.

$$
\text { -. }
$$

*Geothermal Resource Impact and Planning Study 
We also strongly support orderly and intelligent development of geothermal resources in the Geysers region, of which Lake County is a major part:

Conrad Dorn (quoting Muriel Jordan, Secretary of the Geothermal Association for Lake County) "Cobb Mountaineer Expert Witness"

Lake Sun

May 24, 1977

...It is unfortunate that many people in this area don't realize the many values of this form of energy and just listen to the overboard ecologists who magnify every possible disadvantage of geothermal progress and downgrade all its many advantages and our county's needs ...

\section{Ear1 Calvini \\ "Letters" \\ Lake County Record-Bee June 15, 1977}

... Environmental regulations that delay, stop, make more expensive geothermal steam, as well as other energy sources, are becoming more and more serious all the time.

Lake County is extremely fortunate to have this source of energy, tax base, employment, etc.

So if a little disadvantage exists, it has to be because of the greater good of the needed energy and its related advantages.

Art Stensen
"Letters"
Lake Sun
May 5, 1977

LAKEPORT - Bob Roby is hardly your everyday, garden variety protestor-not after 32 years with the FBI.

As head of the Lake County Energy Council, Roby leads the local battle against the forces pushing geothermal energy in a county with enough good weather and other amenities to attract retired folks ... 
... He became involved because he felt 'betrayed' by what he felt was happening to what he considered the ultimate

in retirement locales ...

"An Ex-Believer Takes on the Energy Establishment" San Francisco Sunday Examiner and Chronicle

October 24, 1976 


\section{SECTION FIVE: METHODOLOGY FOR RESEARCH}

A standard method for investigating the distribution of value in a

social system did not exist at the inception of the project. Consequently, the investigators felt that a primary task in the first year of what was anticipated to be a two-year project consisted in the exploration and appropriate selection of those research techniques which could resolve the dilemmas posed in Section One. The reader will recall the utilization of nine basic questions. They were intended to provide a broad base from which to investigate the process of geothermal development in Lake County.

It is important that the investigation be perceived as a system, a set of objects together with their interrelationships, in much the same way as Lake County itself or a larger entity such as California is perceived as a system. . This type of investigation then becomes an "inquiring system" whose conscientious application reveals many of the layers of information extant in the system under study. Each of the nine questions is part of such an inquiring system and is designed not to separate the issues into neat little packages but to provide further access to the remainder of the problem. Fortunately, the order in which inquiries are made does not eliminate whole areas of discourse, so the investigators were free to take what might otherwise be considered a fragmented approach, realizing that ultimately the information gained about the system could be applied to its understanding.

An important factor in ensuring the viability of such an inquiring system is the non-elimination of various paths to information. Care was taken by the investigators that they not eliminate any person or group of persons from consideration in terms of opinions solicited or feasible suggestions implemented. Each proposed investigative technique was thoroughly discussed in terms of efficacy, impact upon the system under investigation, effects on the stance and reliability of the research group, feasibility and ultimate utility. It occasionally became necessary to consult with persons outside the project but nonetheless in touch with the geothermal development situation on questions of propriety and stance. For example, when an item was to be published in a local newspaper, we requested that a member of the local government give the item a prior reading. 


\section{RESEARCH METHODS}

1) Attendance at a multitude of local, state and federal meetings (see sections Seven, Eight and Twelve) provided the team with information regarding the various decision makers, client groups and policy options. This information was pertinent to our assessment, especially in terms of questions: 1 (clients), 2 (goals), 4 (decision makers), 7 (planners) and 9 (contro1).

2) We were specifically concerned that no client or potential client be ignored, so along with attending meetings we talked with representatives of various public agencies who we assumed could act as surrogate clients. It was obviously impossible to assess on a statewide basis the feelings of people regarding geothermal development. Information received in such encounters was treated as second-hand, due to the layers of surrogate clientele, and utilized only to direct our inquiry in profitable directions. We then could follow up with letters, phone calls or interviews with representatives of various client groups. This also became an excellent means for mapping the various decision makers within the system.

3) To balance the conscious inclusion of extra-county client groups we made an effort to ensure that our project remain open and accessible to those whose interests are addressed by this study. Interim reports were published in the four newspapers serving the area. These reports took the form of open letters in the "Letters to the Editor" section. It was our intention to reveal the course of our investigation and to solicit comments and additional information from the people of the county. We feel that this mechanism disseminated information to the public in an efficient way, and that it brought in a wealth of information about the perceptions of the residents of Lake County.

There is a lively correspondence carried on in the newspapers by the authors of various columns and articles and the readers thereof, and we became part of the interchange. We consequently have a large file of letters on hand (some of which are reproduced in Section Nine) and an even larger file of newspaper articles and 
other published material pertinent to the subject of geothermal energy development in Lake County and elsewhere.

4) We have had numerous private conversations with people in the county: We were concerned that we not limit our conversations to a vocal few and consequently sought out the opinions of people from all walks of life.

5) In addition to attending various meetings as observers, we also participated in open forums where we were questioned as to our knowledge of geothermal development and where we attempted to gain a stronger sense of the community's view on the issue of energy development.

We should point out that though we have the capability of designing and conducting questionnaires and/or formal interviews, we did not have time to conduct one nor do we feel that residents of Lake County can adequately deal with the issues of geothermal development by responding to a questionnaire or formal interview. Each person views the future in terms of his or her own perceptual base, whereas questionnaires assume that this base is common to a11. For example, if the questionnaire asks "Would you leave Lake County if geothermal electricity plants were built?," the citizen may find it impossible to respond sensibly because his or her perceptual base does not include an image of plants in the environment. Only by letting each citizen express opinions and perceptions in his or her own way can we begin to understand what the citizens feel and believe relative to geothermal development. We think it is up to the residents themselves to generate information about their perspectives, opinions and values.

6) In addition to these approaches, we utilized our academic setting to access various books and publications, many of which are referenced in the various sections. We also had the opportunity to conduct seminars and field studies with students who further expanded the scope of our research through their inquiry into areas with which we were unfamiliar. 
In sum our methodology consisted in the utilization of various opportunity occasions. The analogy of "searching for clues" as in detective work seems apropos. We attempted to place ourselves where information would be. Such an opportunistic methodology demands a pre-existing structure on which to map the influx of data. The nine questions (see Section One) provide this map and become the starting point for questions more germane to specific issues within the larger client, planner, decision maker or environment question.

The other ability inherent in the employment of the systems approach is that which allows the integration of highly disparate information in a format which carries and does not eliminate knowledge. This in itse1f is justification for the increased utilization of the systems approach in social inquiry.

We will be increasingly faced with problems which do not bend to a technological fix and it is incumbent on the research community to structure its inquiries to reflect the full mix of conditions and options possible. 
SECTION SIX: LAKE COUNTY GEOTHERMAL ENERGY RESOURCE

The Geysers-Calistoga KGRA is one of 24 KGRA's (known geothermal resource area) in California. It has experienced development activity since the early 1950 's. The resource in this area is known as a vapor-dominated resource. This means that the resource is in the form of dry steam which is used to drive turbine generators for the production of electricity. The condensed water from the dry steam is cooled and reinjected into the ground, in the hope that it will partially recharge the area from which the steam was first extracted. There has been lengthy debate on just what kind of resource this steam is. Is it water and therefore under the control of water regulation or is it a mineral and considered depletable? For development incentive, it has been considered a mineral to allow the developers a depletion allowance.

Other KGRA's receiving attention in California are: Imperial Valley in southern Cailifornia, Mono Lake in west central California, the Susanville region in northeastern California, and the China Lake area. The Imperial Valley area is dominated by what is called a hot brine. This is a high temperature water that has a very high concentration of minerals. This resource has been found to be very corrosive and poses a problem of extreme scaling in piping and equipment. The resource is presently being tested in a pilot plant funded jointly by ERDA and the San Diego Gas and Electric Company. There is a great deal of additional activity in the form of exploratory drilling in other parts of the valley. In Susanville the resource is being developed by the city in an attempt to make it a public utility similar to the experience of Boise, Idaho and Klamath Falls, Oregon. 47 This resource is also hot water, as are the majority of the KGRA's in the nation.

One of the environmental problems that have been associated with the development of the Lake County resource is the release of $\mathrm{H}_{2} \mathrm{~S}$ into the atmosphere. This hydrogen sulphide has the odor of rotten eggs and is familiar to anyone who has ever visited an area of naturally occurring fumaroles. There is in addition a certain amount of damage to the trees and ground cover in close proximity to each power plant. The condensed water was a problem in the past when it was dumped into 
nearby streams and drainages. This practice, however, has been reported stopped. There remains, however, the question of accidental spillage and runoff. Another question is about the problem of ground subsidence in the area of extraction. Little is known about the exact response, in each case, of the surface area due to the release of underground pressure. There are indications in other areas of the world (Italy and New Zealand) that such subsidence has occurred. In conjunction with the question of subsidence is the question of seismic activity. There is a question of wholesale development initiating seismic activity. There is also a possibility that, in the event of an earthquake, the casing around the steam wells could be sheared, causing well blowouts which are an extreme hazard and would be especially threatening near built-up areas. Other problems include the closing of public lands to other activities by the leaseholder, loss of wildlife habitat, archeology sites, and natural hot springs. 48

In the Geysers area of the Geysers-Calistoga KGRA, there are presently 12 power plants in operation producing 508 megawatts of power. A new power plant is presently under construction with two more planned for the immediate future. A11 of the presently operating power plants are in Sonoma County in a generally uninhabited area. The plant now under construction, however, is in Lake County. The projected total available resource in the KGRA is 5000 megawatts. * This has to be qualified, however, since the boundary of the KGRA is being continually changed and the methods for assessing the resource potential are both variable in accuracy and limited in scope.

With present technology, it takes from 15-20 wells to operate one 110-megawatt power plant. Another 15-20 wells are needed for replacement of failed wells during the life of the plant. The life expectancy for tax purposes and cost accounting has been set at 30 years. There is little evidence to support this as an actual life expectancy or the counter belief that the geothermal resource is non-depletable. ${ }^{49}$ It takes very few people to operate any of the power plants and wells once a full field of wells had been developed and a power plant built. It does take a larger

\footnotetext{
Don Johnson-Lake County planner
} 
number of people, especially trained for the job, to drill the exploratory wells and to drill the producing wells. These people ususally work for the development company and seldom are drawn from the regional labor pool. The construction of a power plant is similar in that it requires a work force with special training and seldom draws from the local labor force. The need for personnel is very short-lived which means the out-of-region construction workers seldom move their families into the area of construction. 50

There is a possibility that this lack of job opportunities, if true, may deny an anticipated benefit to Lake County, which suffers from one of the higest unemployment rates in California. Another area to explore is the employment picture if non-electric uses are made of the geothermal resource. The experience of other small rural communities has been that the good times have not come automatically. A great deal of thought and planning is needed to insure that, in economic terms, the costs outweigh the benefits. 51,52 Another question concerns a problem that has been brought home to the State of Louisiana. There the state government had grown to depend on gas and oil monies that are now disappearing with their dwindling resource. States like Montana have attempted to prevent this from occurring with their development monies by forming trust funds for the future. If the resource in the KGRA is indeed depletable, then similar issues will arise in Lake County.

Since the geothermal resource is currently a mineral resource, it is possible for any owner of the mineral rights on land to lease these rights to a developer. In the case of the geothermal resource in Lake County, the property owners include the Federal government, especially the Forest Service, state government and private interests. The BLM handles the leasing of federal lands, the State Lands Commission handles state lands, and private individuals are free to enter into contract with any developer under any terms found to be agreeable. In Lake County special use permits for any land use not covered in the zoning designation of private lands must be handled through the County government. Exploratory drilling and what is known as full-field development (meaning that the required number of wells to supply a power plant are to be drilled) are such activities.

For a geothermal development the developer finds the resource in commercial quality and quantity and then looks for the best buyer. In the 
Geysers area the buyer has been the Pacific Gas and Electric Company. Their interest was in using the resource for electrical generation. The developer brings the resource to the fence line of a power plant and from there it is PG\&E's resource. The price of the resource is tied to the price of equivalent fossil fuel sources for a market level that can be taxed and accounted for. There are other potential users for future developed steam fields that include private utilities and the California Department of Water Resources.

An interesting problem arises from the fact that the State of California is responsible for the siting of any power plants in the state. Geothermal is a site-specific resource, however, and the resource cannot be transported over any distance like coal or uranium. Therefore the siting is done de facto by the county governments while giving out drilling permits.

A case that came before the Ninth District Court of Appeals was directly related to this problem. 53 A citizens' environment group contended that the exploratory drilling part of the resources development process is clearly part of a phased development under the terms of CEQA (California Environmental Quality Act), and that the chance of not having a power plant built was quite low once exploratory drilling was approved. The reason given was that the investment by the developer has been substantial and that this is a proven source of much needed energy which in relationship to strip mining and nuclear power plants is by far a more attractive alternative. Up to this time the scope of the required EIR's has been restricted to the specific site of each exploratory well or in the case of a full-field development, to that immediate area of supply we11s. The citizens' group insisted that this activity was just a part of a full-development process that not only included the wells but the power plant and powerlines leading from the power plants. They were insisting that a comprehensive EIR is required for the full-development process and there is not enough baseline data available for that kind of EIR to be written at this time. The case was decided against the citizens' group which means exploratory drilling can be done without a full-field EIR.

There are a number of questions and issues dealing with full-field development, including the number of possible power plants, non-electric use of the geothermal resource and all so-called secondary impacts that still require further study and should receive more attention. This will 
include trying to understand and help plan for the generic problems of growth and change in communities faced by development of this type; e.g., do the emerging views of the development process call for more comprehensive EIR's and baseline data collection to back up the EIR's or for a streamlined EIR process of some sort that would cut through the red tape and cut the cost and time required to get on with the development?

In all the confusion and 1ack of direction connected with geotherma1 development, the Lake County planning staff took the initiative and developed a proposed planning framework around which planning decisions, EIR writing and evaluation could be organized.

After a certain amount of effort to obtain funding and approval from their own board of supervisors, the planning staff looked towards the state and federal agencies that were most heavily involved with the development of the geothermal resource. This meant making presentations to the State Energy Commission and ERDA. These agencies and a variety of closely related agencies have over a period of time funded a great many research projects and demonstration projects related to geothermal energy. It soon became apparent to a number of people trying to deal with the issue that the resource and its effects did not respect county boundaries. Because of this multi-county relationship, the Lake County planning staff presented their proposal to each of the three other counties that were included in part in the common KGRA. Each in turn decided to organize their common efforts around the framework whose acronym becames GRIPS (Geothermal Resources Impact and Planning Study). The four counties then presented the new GRIPS management organization to ERDA and State Energy Commission members to ask for participation in this specific program (see Figures 1 through 4). Both governmental groups had been aware of the GRIPS program and even though both groups came with a list of probable scenarios for development, they agreed that they would participate in this project. It was agreed that a central policy committee would be formed from representatives of the four counties, ERDA and the State Energy Commission. This group would decide what issues needed to be studied and if the studies were adequate. It would also be the task of this group to collect all of the relevant studies already done and to control any further studies in the area. The final product was envisioned as a map showing areas where development could or could not take place. 
The Governor signed into law Assembly Bill 3590 (Kapiloff) on August 27, 1976. This bill set up a State Geothermal Task Force to answer 16 questions on geothermal resource. The hearings were held in Sacramento (April 14-15), San Diego (April 28-29), Sacramento (May 19-20) and San Francisco (May 26-27). The results of these hearings are being published by the Task Force (see Section Twelve).

GRIPS has initiated workshops in each of the participating counties to allow citizens to comment on geothermal development as it is taking place now and how they think it should take place in the future. Environmental Systems and Services of Lake County is also planning to. hold a third seminar on geothermal development.

The Lawrence Livermore Laboratory has also started a research effort similar to the one they did for Imperial Valley which hopes to collect baseline data useful for assessing geothermal development.. Other research efforts connected to geothermal development are taking place in a wide variety of industrial and governmental agencies. The question of how much and what kind of research is taking place and what kind may be necessary to initiate in the future requires further study and assessment.

Many questions about the way development is now taking place technically, politically, socially and economically and suggestions for improvements in the future were to have been dealt with in this study. This has not been possible because of the termination of the study by ERDA and the Lawrence Berkeley Laboratory. 


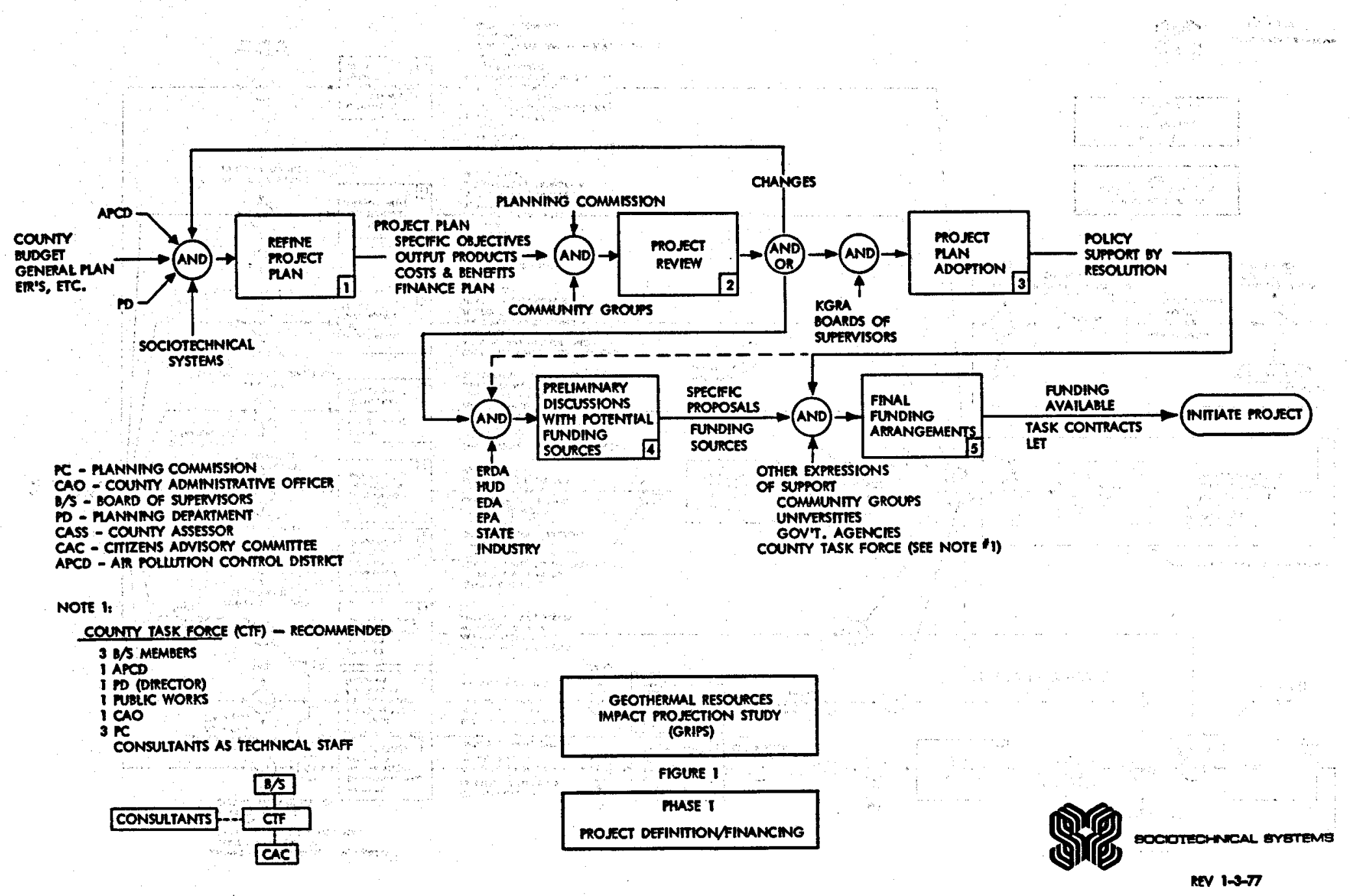

Figure 6-1

XBL 782-7263 


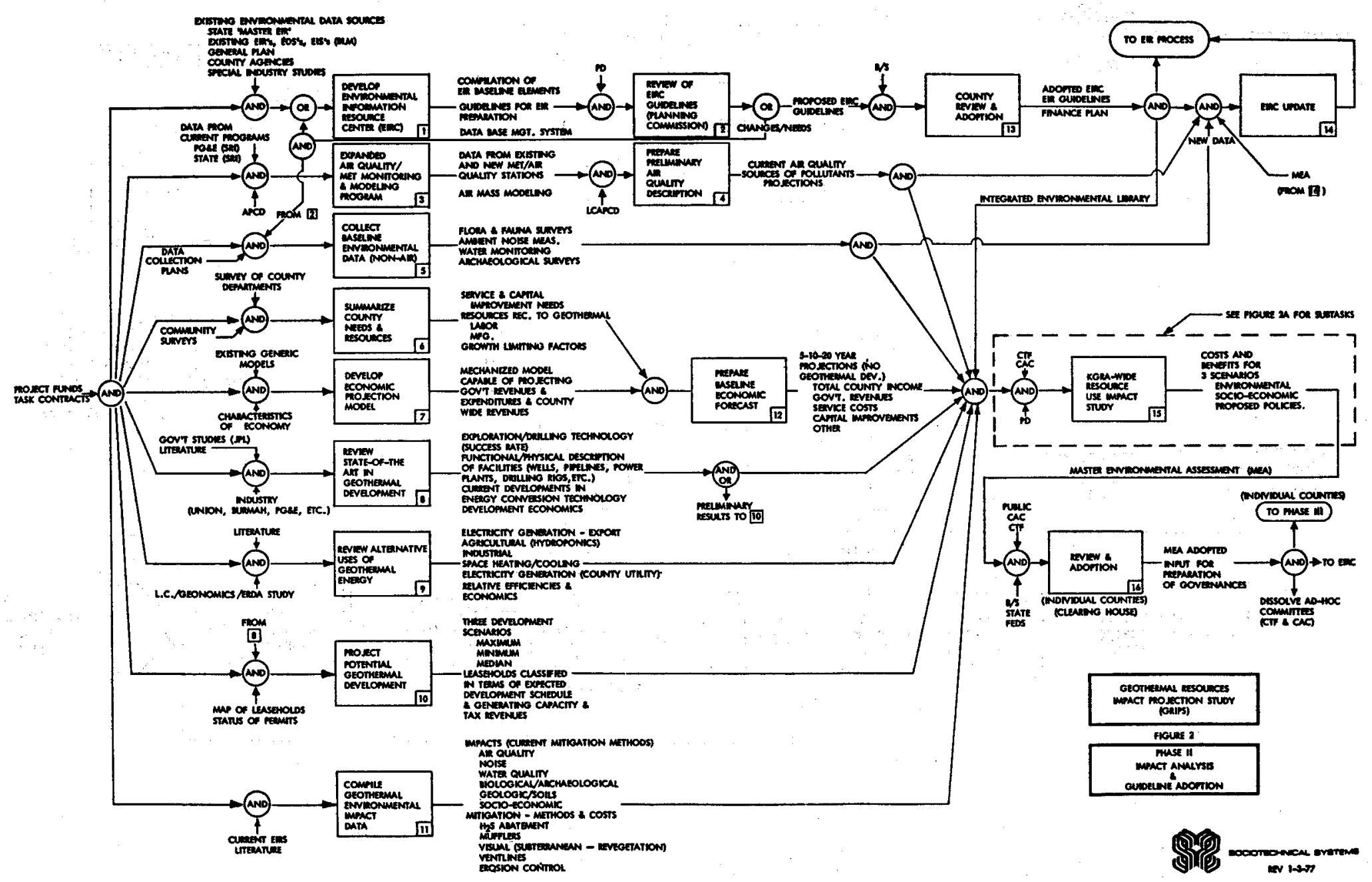

Figure 6-2

XBL $782-7264$ 


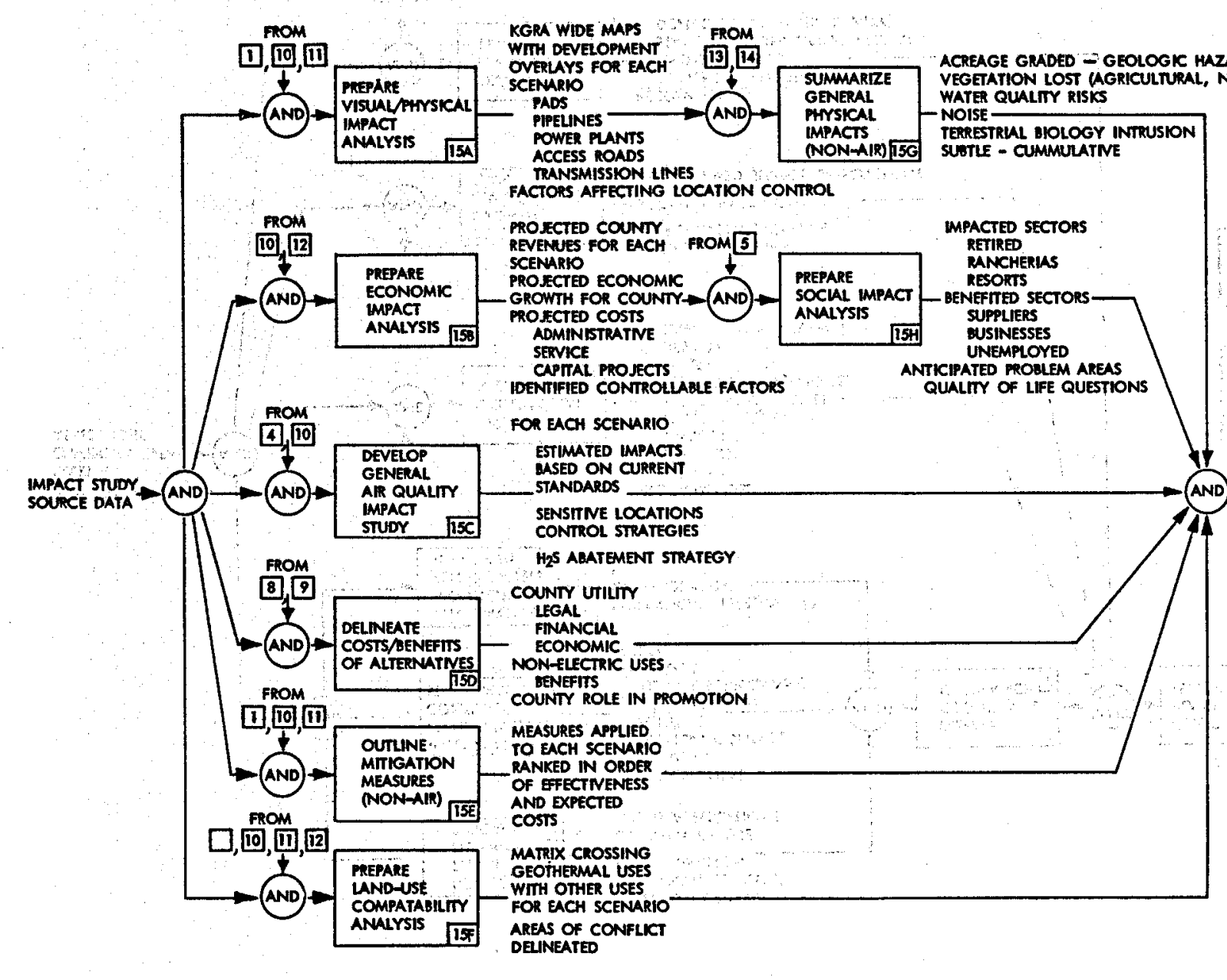

Figure 6-3

COSTS AND BENEFTS

DISPLYYED FOR EACH

SCEMMRio

PREPARE AREAS OF UNCERTAINT
PLAINLY IDENTIFIED

REPORT RECOMMENDATIONS FOR

PURTHER STUDY
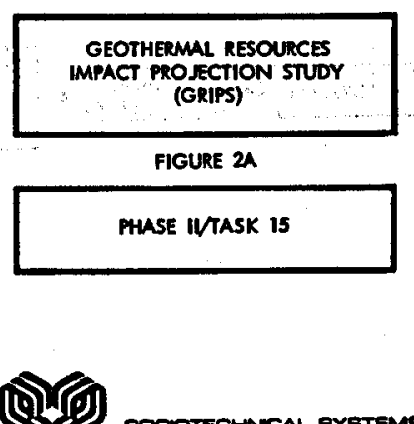

REV 1-3-7

XBL 782-7265 


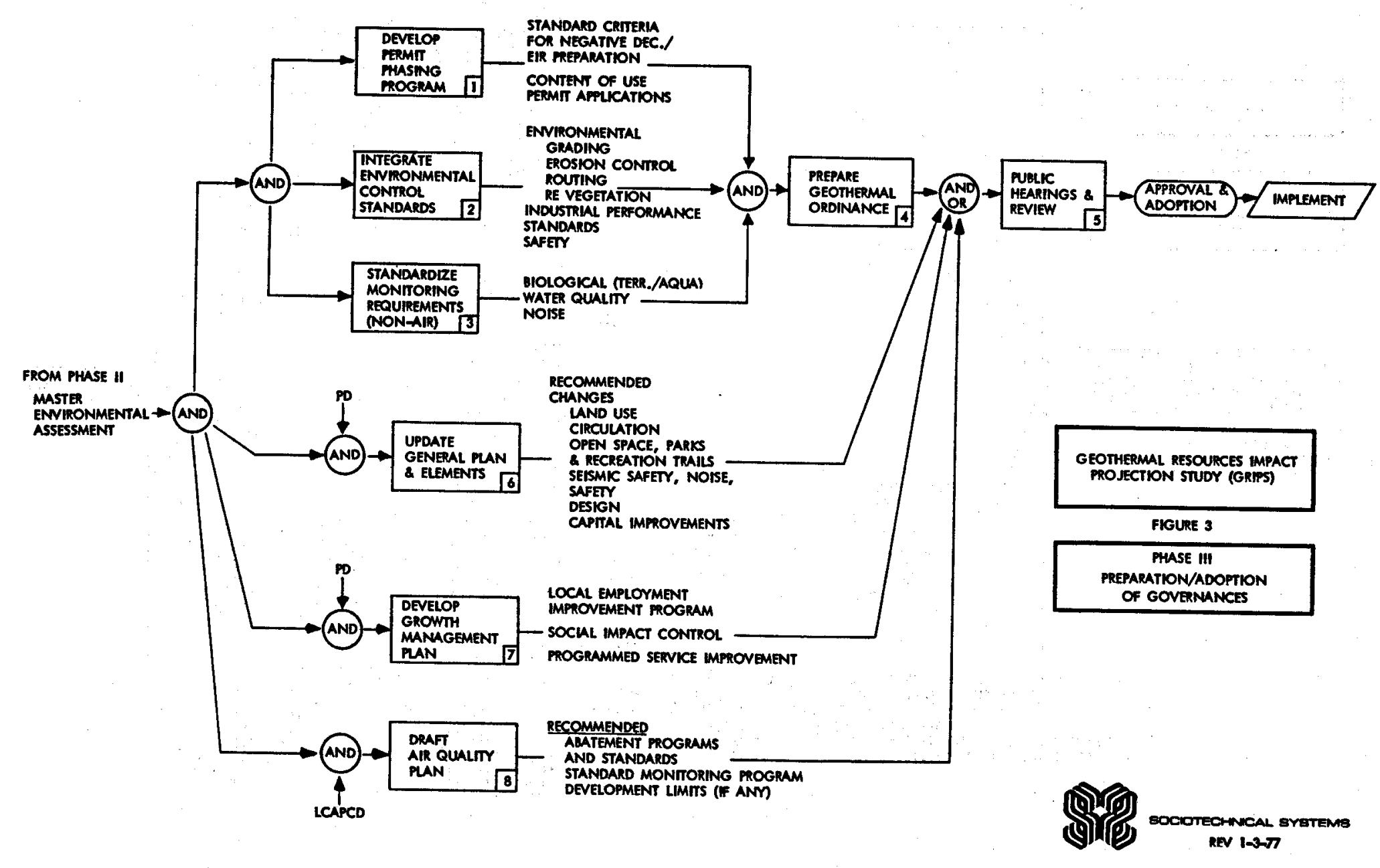

XBL 782-7266

Figure 6-4 


\section{SECTION SEVEN: DECISION MAKING}

The following table (see Table 1) of planning and decision making bodies related to geothermal development in Lake County and the flow diagram (see Figures 1 through 6) showing the decision-making process as it relates to the specific instance when the county is lead agency were to have served several purposes. Many of these must remain unfinished because of the termination of the research project.

The long list of potential planners and decision makers indicates the great numbers of people who are potential and actual generators of data and information that must be taken into account as decisions are made about the way in which the geothermal resource is developed in Lake County. The flow diagram shows the theoretical framework for decision making; where key decisions are made, by who, what documents are produced and where inputs of information occur. The questions that arise when comparing the table and flow diagram are: (1) How best can the great quantity of data and information be collected and utilized within this framework? (2) Who should or should not be a part of this decision making? (3) How can the major decision makers be best aided in their task of making judgments? (4) How could the framework be better structured to improve decision making? (5) How would GRIPS and similar programs best be related to this framework? (6) What kinds of data and information are needed for this process? There are probably a number of other issues as we11, but this partial list serves as an example of the intent in developing the list and flow diagram. 
Table 1

Planning and Decision-Making Bodies Related to Geothermal Development in the Lake County GSRA*

The following is a partial list of the major actors in the development of goethermal energy in the Lake County KGRA; FEDERAL

U.S. President

U.S. Senate

U.S. House of Representatives

Environmental Protection Agency

Energy Research and Development Administration

Division of Geothermal Energy

Policy Research

Advisory Group

Department of Energy (formerly ERDA, above)

Department of Agriculture

U.S. Forest Service

Regional Forester

District Ranger

Department of Interior

U.S. Fish and Wildlife

National Parks Department

Bureau of Indian Affairs (Rancherias)

Youth Conservation Corps

Bureau of Reclamation

Bureau of Land Management

U.S. Geologic Survey

Area Geothermal office

Departmentof Health, Education and Welfare

Public Health

Department of Labor

U.S. Army Corps of Engineers

Department of Commerce

Court System

Federal Energy Commission

Federal Power Administration

*Known Geothermal Resource Area 
Table 1 (continued)

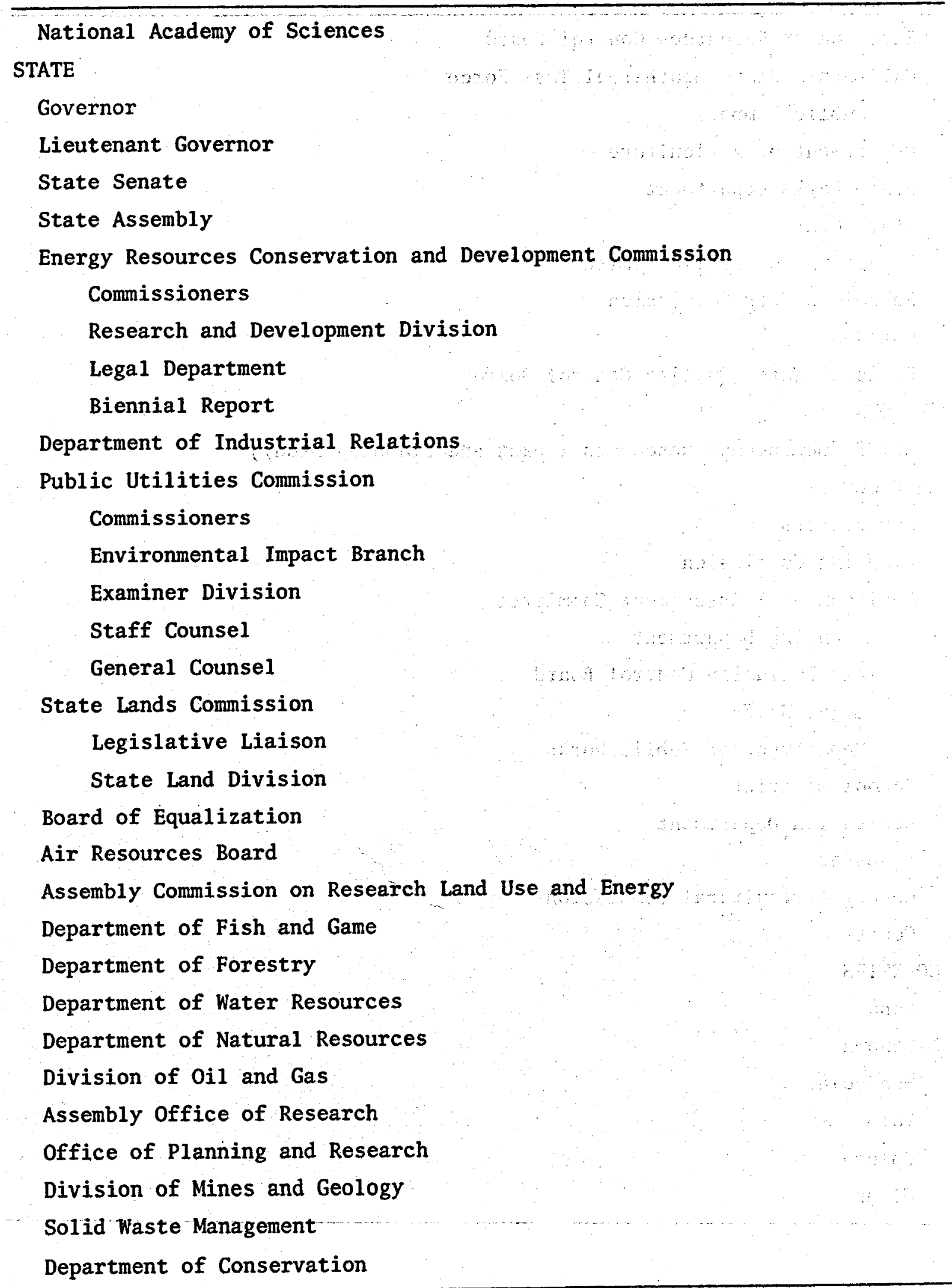


Table 1 (continued)

\author{
State Water Resources Control Board \\ California State Geothermal Task Force \\ Public Members \\ Department of Agriculture \\ State Parks Department \\ State Courts \\ Department of Public Health \\ Seismic Safety Commission
}

CALTRAN

Regional Water Quality Control Board

REGIONAL

GRIPS (Geothermal Resources Impact and Planning Study)

LAKE COUNTY

Supervisors

Planning Commission

Environmental Assessment Committee

Planning Department

Air Pollution Control Board

Legal Staff

Department of Public Works

School District

Recreation Department

Assessor

County Agricultural Commission

Courts

COUNTIES

Napa

Sonoma

Mendocino

Yolo

Colusa

Glenn 
Table 1 (continued)

TOWN-CITY

Clear Lake Highlands

Clear Lake Oaks

Lucern

Nice

Upper Lake

Lakeport

Mayor

Kelseyville

Middletown

Lower Lake

UTILITIES

Pacific Gas and Electric

Northern California Power Agencies

INDUSTRY

Burmah Oil

Republic Geothermal

Chevron 0i1

Thermal Power Company

Coopers and Lybrand

Union Oil Company of California

Diablo Exploration

Thermogenics

Getty 0i1

McCulloch

Imperial Magma

Phillips Petroleum

Magma Power Company

Various Construction Companies

Natoma Company

Pacific Energy

Drilling Companies

Real Estate Companies

Labor Unions

Bank of America

Aminoil

Wells Fargo

Crocker

Merrill Lynch

Dean Witter

Energy Marketing and Management Assoc.

Bank of Montreal

United California Bank

Argosy Corporation

California Association of Realtors

Lawrence Berkeley Laboratory

Lawrence Livermore Laboratory

California Institute of Technology

Jet Propulsion Laboratory

University of California

National Science Foundation

Stanford Research Institute

Geonomics

EIR, EIS Preparers 
Table 1 (continued)

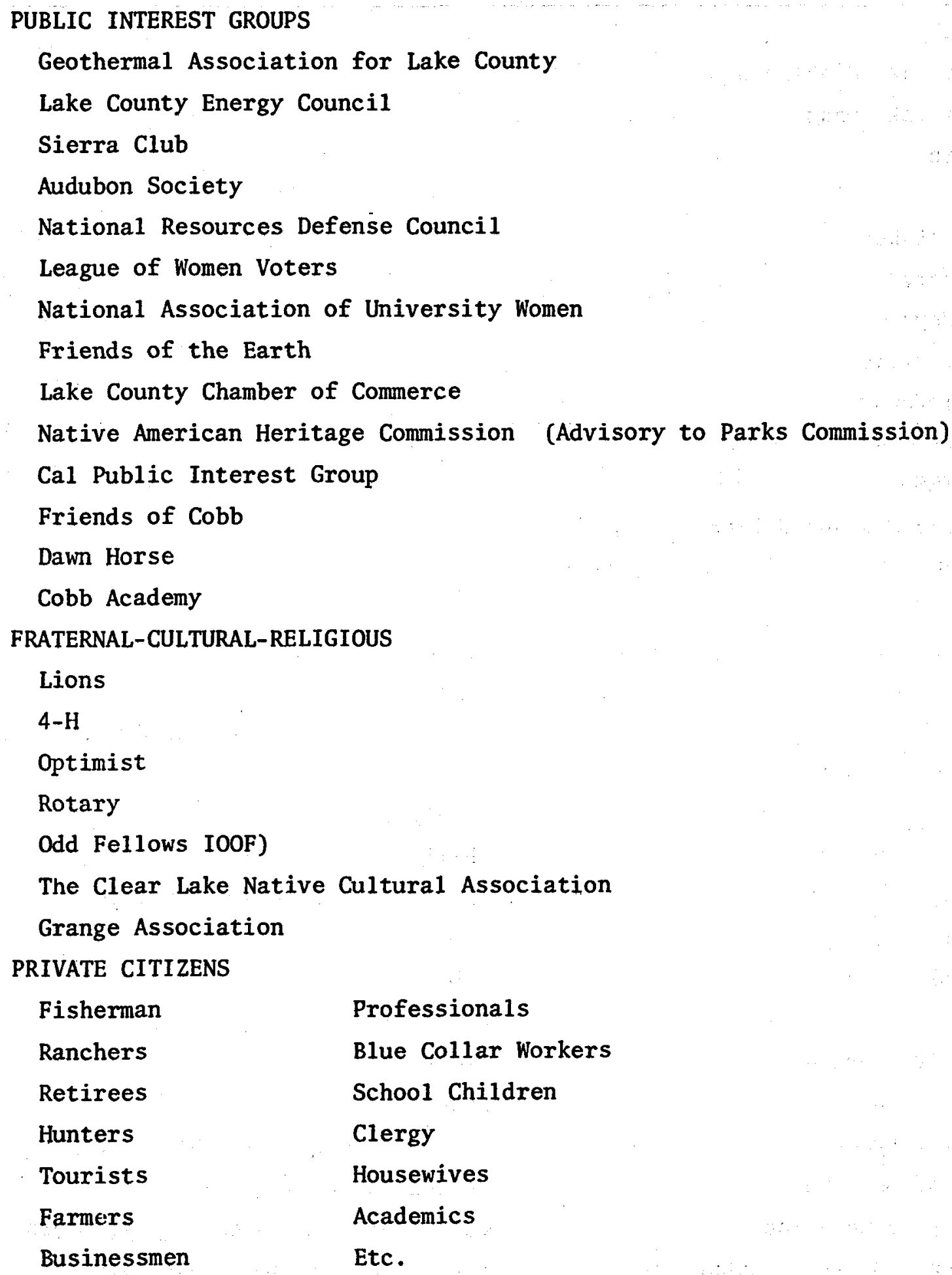




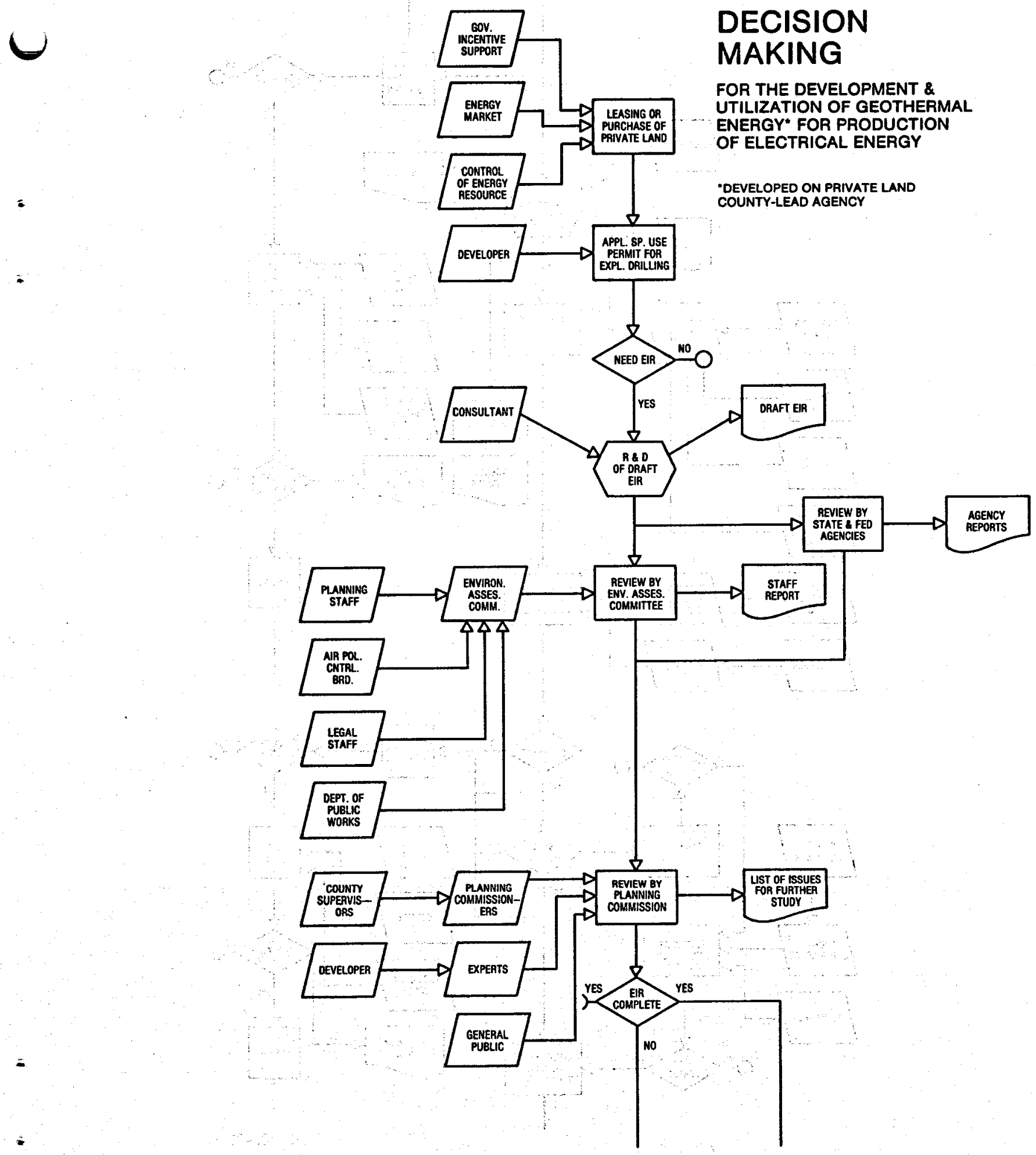

XBL $782-7272$

Figure 7-1 


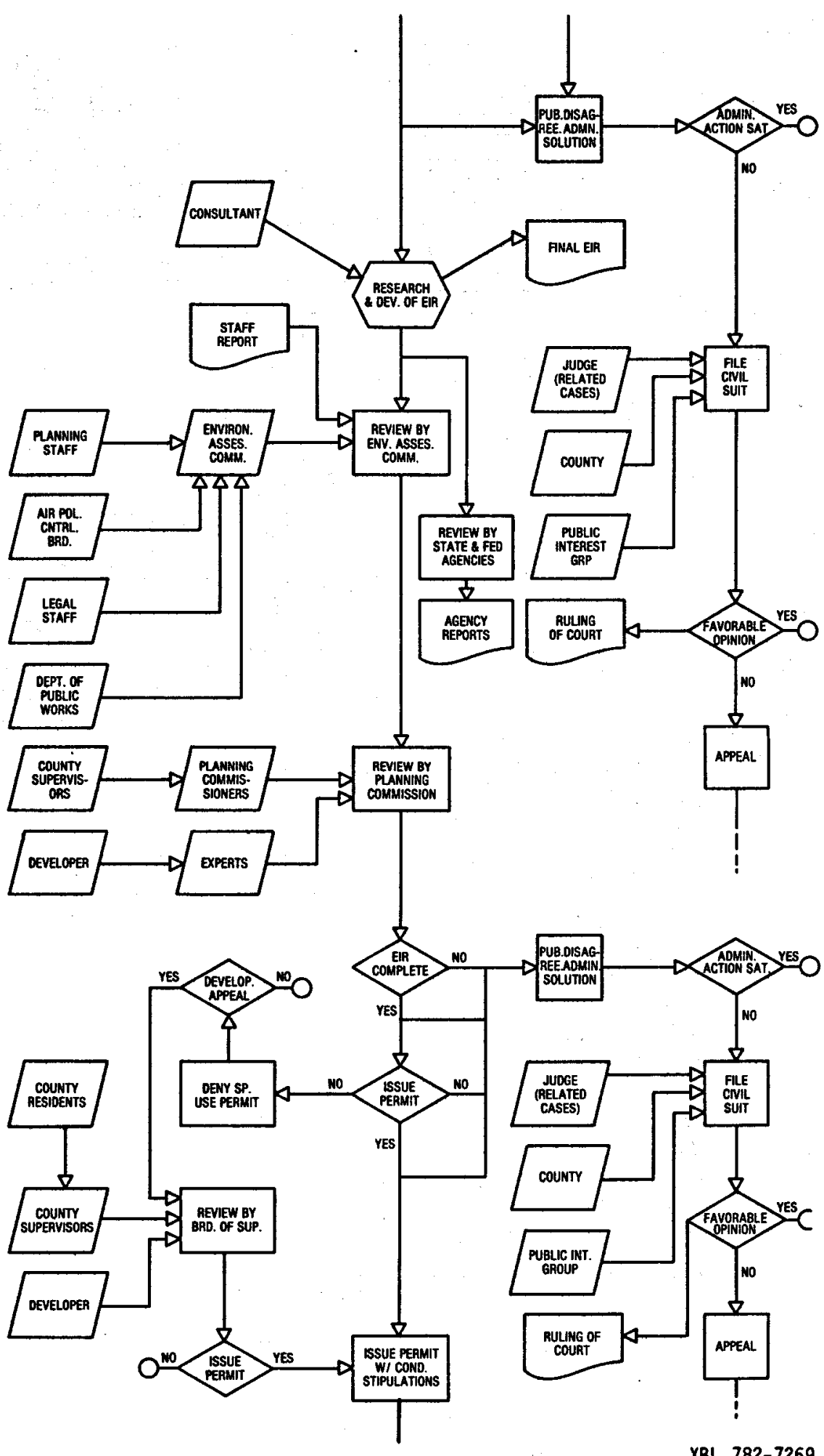

XBL $782-7269$

Figure 7-2 


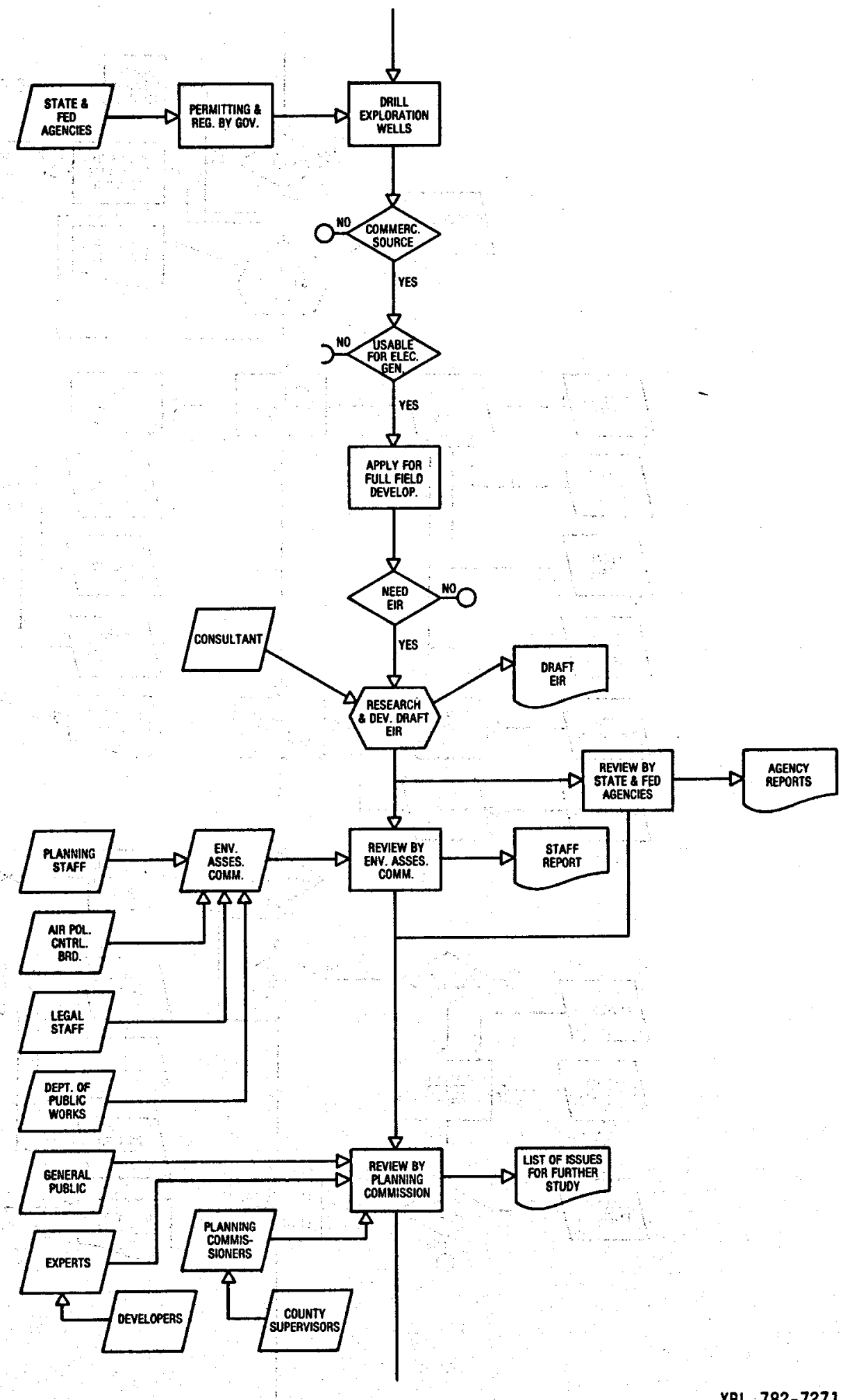

XBL $782-7271$

Figure 7-3 


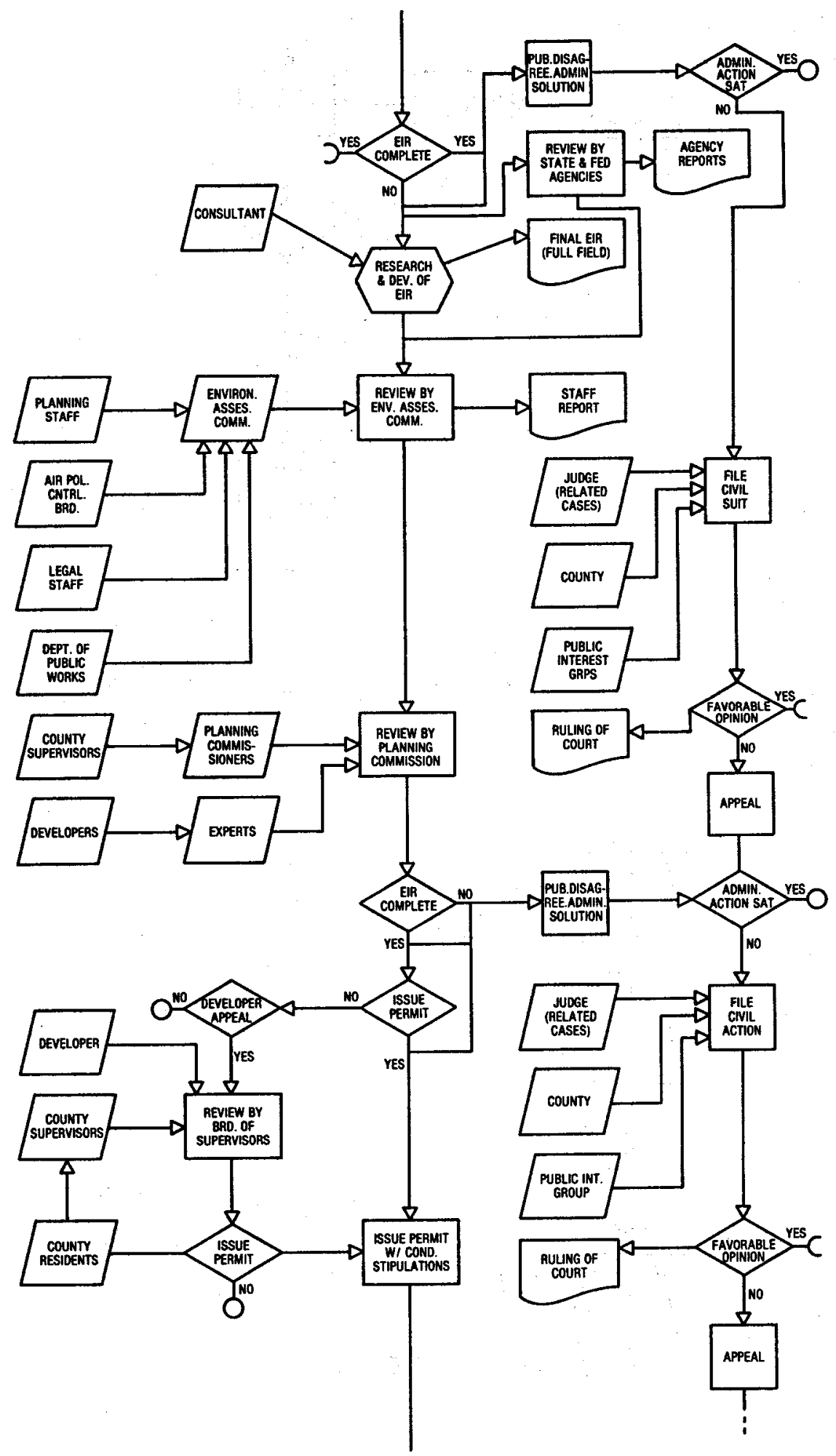

XBL $782-7270$

Figure 7-4 


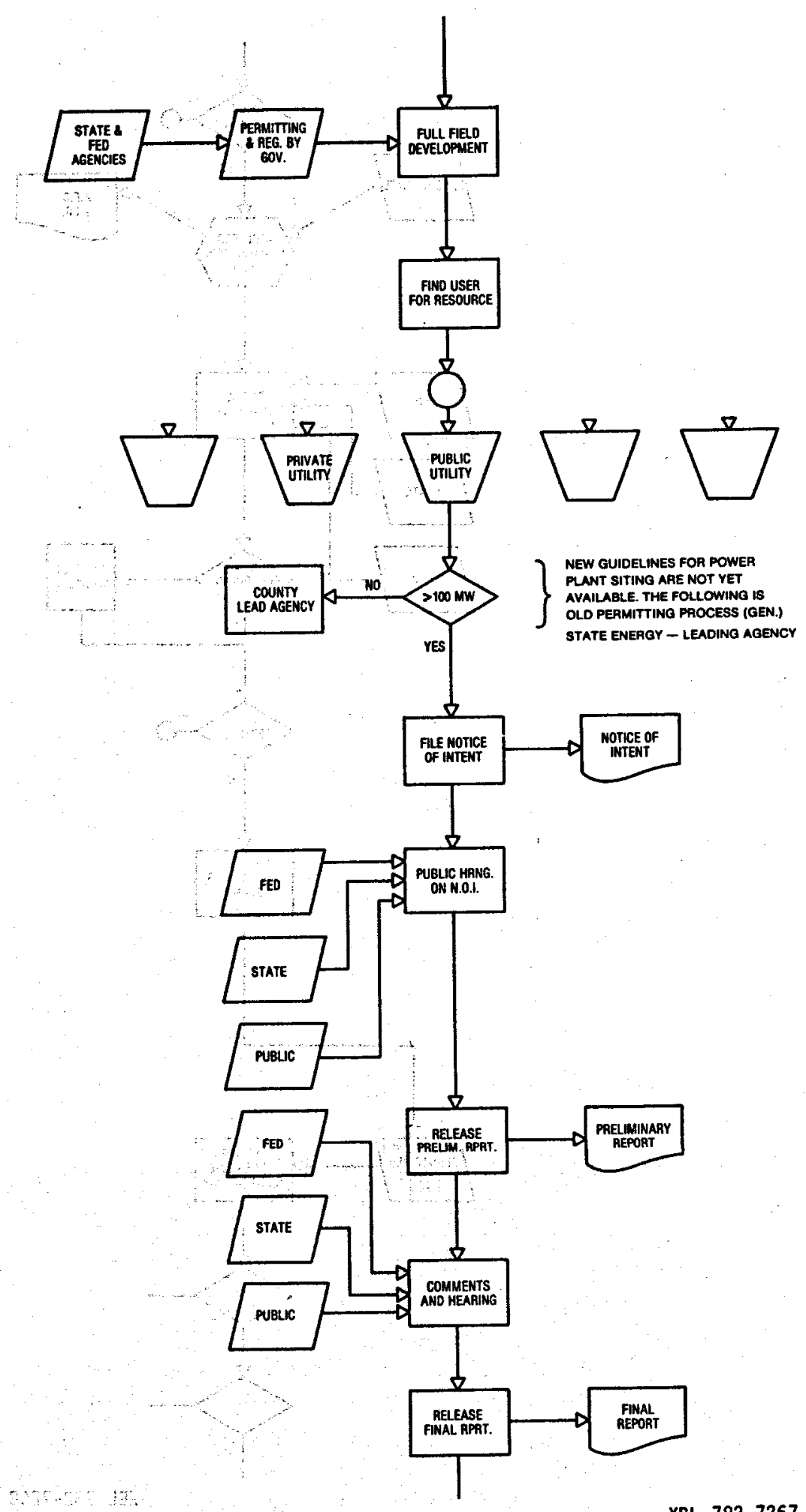

XBL $782-7267$

Figure 7-5 


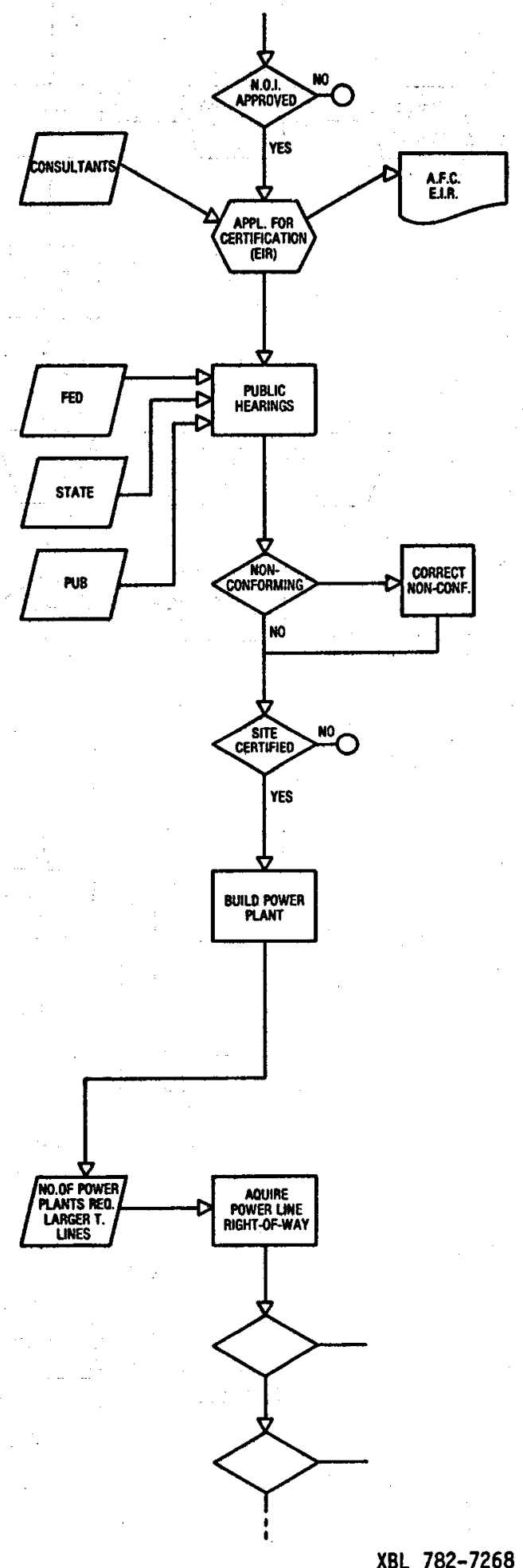

Figure 7-6 


\section{SECTION EIGHT: PLANNING COMMISSION HEARING}

Another move has been made to introduce geothermal development into an area that is primarily residential and quite unlike the remote, unpopulated areas that are now developed. This move came in the form of an application to the Lake County Planning Commission for a permit to drill exploratory wells on a leased tract of land by McCulloch Oil Company in the area known as Cobb Valley. The hearing held on June 9,1977, to consider the completeness of EIR submitted by Mculloch Oil serves as a good example of present planning difficulties and points to future issues to be resolved.

At the hearing the Environmental Assessment Committee recommended to the Planning Commission through the Planning Department that the EIR be accepted as complete as measured against the requirements of CEQA. The completeness of the document is based on the professional judgment of the Environmental Assessment Committee made up of the County Planning Department, the County Air Pollution Control Board, the County Legal Staff, and the County Department of Public Works. Public input was expected to occur prior to this hearing as, according to the planning Commission, CEQA did not oblige the Planning Commission to listen to public comment on hearings related to the final EIR. They did, however, listen to some presentations from citizens at this hearing. The document was accepted as complete. According to the planning staff, all issues raised by the public and governmental agencies had been adequately dealt with in the EIR.

The applicant brought a large, colorful three-dimensional topographic model of the lease area that was the object of the EIR. This presentation left out much of the important information to making informed judgment as to the wisdom of the proposed development, leaving the purpose of such a prop open to question. The questions and concerns from the public were indicative of the existence of a polarized community with no access to the volumes of studies completed on the subject of geothermal development. The experts representing the applicant easily dealt with the literal content of any concern voiced by a resident while ignoring the larger implied concerns. 
Although the EIR was considered to be complete, it did not address issues related to anything other than the immediate and isolated act of drilling exploratory wells. A major issue to some interest groups and to such governmental agencies as the State Energy Commission is the need to consider an activity as part of a large-scale development. Lake County. may, if it so chooses, conduct such an holistic approach. Due to the twin factors of time and money, the permitting process has evolved into one of looking at each specific request as an isolated event. Thus, the three-dimensional model brought in by the applicant did not have to indicate the leased area adjacent to the one in question, nor the location of power plants, roads or overhead powerlines and how this development would relate to others. The EIR did not have to include issues related to effects outside the synthetic boundary of the leasehold.

The Planning Commission for Lake County is directly responsible to the Board of Supervisors, as each commissioner is appointed by one of the supervisors. Any decisions made by the Planning Commission can be overturned by the Supervisors. The planning commissioners do not have any special expertise in planning and must rely on staff reports from county agencies and on directions from their individual supervisors. There are few if any contacts with the Planning Department to discuss planning theory and methods or other educational topics. In the case of this hearing on Cobb Valley, the Planning Department met with the applicant and the consultant who wrote the EIR to work out any details prior to the hearing.

Several things become apparent when this specific incident of a hearing before the County Planning Commission is seen in perspective and compared to other activities related to the development of geothermal energy. First and most important is the question of the relationships of such information gathering activities as GRIPS (Geothermal Resources Impact and Planning Study) to the realities of government in Lake County. How will the GRIPS information be used and by whom? For the county agencies already overwhelmed by information, how will more be used to help in the decision-making process?. The State of California just completed extensive hearings on the development. of geothermal energy prior to this hearing yet none of the issues were brought to this hearing (see Section Twelve). How could agencies like the State Energy Commission provide information to such hearings? How could ERDA relate to the development of energy at this scale and focus? How are the studies completed by experts and professionals to be used by 
this county structure? If the county cannot utilize this vast supply of information, how can the development process be restructured? Would it be possible for agencies like ERDA to act as advocates in educating the communities and government leaders in the issues related to resource development?

of real concern is the fact that development is taking place in an ad hoc, piece-by-piece manner, without a considered plan for the future of Lake County, whether it is to remain agricultural-residentialrecreational or is to become industrial as well. 


\section{SECTION NINE : COMMUNICATION EXAMPLES}

It was quite important to the research team that open, two-way communication be established with the residents of system under study. It is painfully apparent in many impact assessments that no attempt has been made to open the assessment process to the input and suggestions of the population ostensibly to be served. The following letters serve as an indication of the depth of feeling aroused by the prospect of geothermal development. We do not make any attempt to editorialize on the themes here represented, but we have deleted the names of the writers (except where the letter is sent under an organizational letterhead). The decision to delete the names of the various writers was made due to the nature of some of the comments made, the possibility of causing undue difficulty for the various writers within their community, and the assumed private nature of their communication with us.

Many of these letters came in response to two interim reports which the research group published as "open letters" in the various local newspapers. These two letters are reproduced first, followed by a sampling of corresponence received.

The final two letters in this section are copies of those sent by the research group to the two major energy-oriented community groups in the county, proposing the staging of a futures fair for the county wherein the various elements of the community could meet to explore alternatives and share aspirations. This proposal never got past the initial planning stage due to the curtailment of the project.

AN OPEN LETTER TO THE PEOPLE OF LAKE COUNTY

We are a group of researchers from the Lawrence Berkeley Laboratory and the University of California at Berkeley who have been hired by a Federal agency to study the effects of a large-scale energy program (the geothermal development in Lake County) on the people in the area of the development. The Federal agency is the Energy Research and Development Administration (ERDA), and the type of study we are doing is called a 'social impact assessment.' 
The questions we are trying to answer are related to the effect of geothermal development on the social we-1-being of the community. What is meant by social well-being, of course, depends on what people believe is right and good about where they live and what they do for a living. It also depends on what they believe would be the most desirable world to be left to their children and their grandchildren.

Here are some 'social impact' questions for residents of Lake County to consider:

1. Will some people benefit and others lose if there is a full-fledged development of geothermal energy in Lake County?

2. If the county receives additional tax money from geothermal development, how should the money be used?

3. Will the plants, we11s, pipes and overhead power lines really change the character of Lake County's environment?

Answers to these questions dealing with what you as citizens of this area believe to be a desirable way to live cannot come from us as specialists nor can it come from any other expert. It has to come from you. Therefore we would like to ask for your help and suggestions. We invite any individual, group or organization to contact us and tell us how the people of Lake County could best tell us their story. We want to emphasize that we would like to hear from everyone. This includes the very young and the very old, as well as service groups (such as $4-\mathrm{H}$ ), and social groups, newcomers and old timers.

In turn we hope to let you know what the many different outside agencies and study groups are doing in relation to the geothermal development program.

Howe we would accomplish that would again depend on suggestions from you on what is the best and most useful means of getting this information to you. We realize that everyone does not have the time to attend meetings or read long, involved reports, yet we feel it is very important to do what we can to let you know about the policies and decisions and the reasons behind then that are being made which directly affect your lives. This problem is common to a large variety of rural communities across the country that are facing similar problems. Any solutions you as citizens may develop from helping us in our study will be useful for them as well.

We will be periodically distributing interim reports letting you know how we are progressing in our study and what we have found out from you in answer to some of the above questions. 
You may contact us at:

Rm. 3125, B1dg. 90

Lawrence Berkeley Laboratory

Berkeley, California 94720

415-843-2740 x6039

C. West Churchman

Harold G. Ne1son

Kreg Eacret

AN OPEN LETTER TO THE PEOPLE OF LAKE COUNTY, \#2

In our March letter introducing ourselves as a research team from the University of California, we expressed a basic concern with the issue of benefit and loss for the people of Lake County from potential geothermal development. As a possible means for assessing the flow of benefits from such development, we are concerned with the flow of tax monies: How much? Who may receive it? Who should receive this money? What can be done to insure equitable distribution?

Our last letter included some questions regarding benefits, to which many interesting responses were made. We would like to hear from the residents of Lake County gaain, giving us their views on the above questions or other issues which are pertinent to geothermal power and life in Lake County.

As reported in the newspapers recently, there was a tax income in Sonoma County of $\$ 3.6$ million from the Geysers project. It was distributed as $52 \%$ to schools, $15 \%$ to special districts, $33 \%$ to the general fund. We are hoping to receive further indication of actual distribution from the Sonoma assessor.

Assuming that development will eventually take place, do you feel that a similar tax bonanza will materialize for Lake County? Do you feel that the benefits of such a dollar influx would outweight the detrimental effects of development? There have been several proposals for potential use of such funding, including improvement of schools, roads, irrigation, and property tax relief. What other programs deserve support? What are the implications of increased dependence on geothermal tax revenues if it should happen that the resource be depleted? What burden is being placed on the future? 
We would appreciate any communication from you regarding these and other Lake County issues relative to geothermal power. Thank you.

Sincerely,

C. West Churchman

Harold G. Nelson

Kreg M. Eacret

Geothermal Research Group

Room 3125-90

LBL

Berkeley, Ca 94720

The letters which follow are photo reproductions of correspondence by and with the research team. 
Yercb \& 1977

Gentlemen:

In regard to your open letter to the people of Loke County.

Ly wife and I retired bere fros. Cakland 14 gears ago. Wh built our home ond developed one acre of land for our own use.

Qusatior Fl-WIII cone people benefit and othors lose? Yos, beceuse pooplo who heve fapd laced to 012 compange w1ll benefit as they do not bave to 11rofinen the royalties come in and the other is the County Goreranent which will become larger. We the property owners will ouffer unlese the gootbermal energy 1s developed ond controlled eccording to Reriromental Impact.

Question \#2-If the county recelres additionel tex money from eoothermal devolopment, the money ohould first be used to cut property taxes, second to bulld all the county roals and third for schoole and educetion.

Question f3-ile bellere in derelopment of energy but not as it is in Sonoma County. The Geysers wick are located in the North Sost part of the County. For orer 75 equare alles there are no people 1171 ing there wile in laks County thare is not one equare mile uninhablted. You will find of least fivo or nore fanilies in thet orea. We cuffer from the hydrogen eulfide odor add alr pollution plus nolse and fou look at well pipes which carry steam rom the wills to the power plant, 4 leet abore the eround. Thot mag bo 0,K. In Bonome County where there is no one around but in Inke County $1 t$ wII be a daseter. The over hoed power line does not anter.

The facts are that over talf of the people 117 Les in Iake Counts cone rror other areas to retire and for recreation and those are the peoplo who actually doreloped and pald taxes.

If the Reotharmal energy is to be developed in Iake County it has to bs controlled and dovoloped where it 18 not populeted one pipo lines should be pleced under ground. It w111 cost norn but it oll1 be improvenent. 
Xarob 20,1977

Qentlemen:

In responee to your requeet for responses from ite ivpli 1 citirenty on the "rocisi luptct" of geothermal development 1 thin Lake Oounty, wy views might besummarized as follows:

I feel that there are oome arcas that oould and ohould be utilized within the county for goothermal development provided oultable oontrols are plaoed on the emission of hydrogen sulphlde gaees, and to arold the pbilution of Burfece waters resulting from splilage of drililing muds, Geothermal brines and steam condenoate. Basioally, I leel thet the areas Involved ahould not be in looations which rould provide an eyeoore to the general public and racation18ts. I do, however, foel that there are areas, probably In close proximity to the exloting flelds of The beyers in sonome oounty wiob oould meet ouch a criterla. Buiteble ocreening by use of last groning evergreens, etc., ohould be a reoulrement to keep the vibual 1mpact of the planti, oervice roads and pipelines to minimb. $\triangle 8$ far aB use of the tax money 18 oonoerned, intilaily, et least, I would prefer to see It given to the Oounty's general fund in order to bring dom the property taxes in this area of predominately retired poople ilvins on emall inoomes. 
Dear Fu'les:

7 reir' your article asking for insut into the feelinss of peonde in lake wunty reganding geothermal progress.

I an very gla! to have sumeone responsible Look into the siturition as $J$ an so disciusted and' disanointer! in the so criller! 'nerg!" Council as $?$ werit there to learn about gentherinal usaje an: 'oun.' ther to be so opinionater' that anythins that come us that misht hrive any possibility of an arivantaige to grothromal progzess uns imneriateis put cloin an! eitirn niriculer! on ignoned. I went once but will not go again as it is so one sicied it has no value.

From all'j've Learner! of it to date, 7 an ciefinitely in favon o' it an! fech its value to us is fan above its disarivuntages. I an arore that there are disar'vantaiges but if seens that they are being overcone nrther ropirlly. Just within the past 'el: ciays the $P C$ C \& say they are going to spenr? $\$ 5$ million doliars on overcoming smell $(H 25)$ an? I unc'erstan? that the oil conninies are also nather nupidly workine on projects to do way with most of the problems.

I feel the need of adritional energy is 0 : prime impontance and it'a possible we may have to make some sirall sacrifices. Also this county needs the income barlly both from the onilugnent involved as urell as the tax base it wouls! provir'e which could? hopefully cut the taxes for the smail property oiners. ? also feel that the sirle posibilities of stean heated hot houses for arriculiure and possiótilities of heating of hot ureter an! homes.

Ho pe this lets you know how many of us feel and that the overboan! eculogists ans greatly out of line in many of our opinion.

Sincercly, 
Dear Researchers:

As custodian, and co-donor with my deceased husband, of Madrone Audubon's W1ldlife Refuge above Middletown, and preparer of 2500 specimens toward a young botany protege 's eventual Flora of Lake County, $1 \mathrm{t}$ is obvious that the values I atth to Lake county are not the accepted ones of gaining the fast buck.

But as younger generations are shifting away from the "estabilshment's" patterns, I, with a couple of Kelseyville and Lakeport naturalists happily am no longer a lone volce crying in the wilderness.

The division between We Have To Have PROGRESS and those who are aware of natural beauty and human's dependence on the chain of life that maintains 1t, the possibility of stringent curtailment of waste to reduce the panic about ENERG is so complete $1 \mathrm{t}$ is hardy possible to dent the ironclad resistance to comprehending the change an industrial economy w11l make in Lake county. The bltter name-caling in print by those who feel their constitutional rights are Infringed by any caution toward Instant development of geothermal sources ea symptomatic of the. logic-tight compartments set against any non-entional appeal to reason. I merely live in harmony with my fellow citizens, feeling it impossible, and sneakily indoctrinate small children in nature walks as my contribution toward the future.

From the top of our small h1ll whlch comprises the refuge, the most obvious existing change 18 the loss of view of Cobb Mt. when the wells are "bleeding."

In the past winter of drought, the beautiful pool in Dry Creek near Chevron's arill site was murky with creosote for weeks after saturated timbers had been affixed to strengthen the old bridge for the passage 
(2)

of their ponderous machinery. The courteous P.R. man from Chevron's San Francisco office phoned to ask me what location most needed protection along the stream, and gave assurance no disturbance of the stream bank would be made within 150 feet. (BLM asks 700) The land was levelled, right up to the edge at the crossing, for no apparent need, the interesting flora scraped off and grass seed plously sprayed on. Obviously what is promised by thoughtful supervisors will not be followed by roistering laborers, whose level of joy is rloting in the bar on Saturday night, unless the companies who will make the money have rigid inspection. The county cannot ride herd constantly on the scattered sites.

The naturalists' greatest joy is untouched wilderness, so there is a revulsion at sight of mechanical intrusion in quiet places. Previously I had entry from all the big land owners about for taking small friends on nature walks and making my botany surveys. We have lost a great deal of area already behind the developers' necessarily locked gates and No Trespassing signs.

There seems little recognition, in the Gold Rush type of excltment for geothermal development, of the great amount of money 1 t has cost the county already in, paper work and additional employees. If a real profit appeared, Lake County's first use of 1t should be for stronger law enforceffrn and 'facility for counseling disturbed delinquents who now have open season for vandalism.

Then reforestation, water conservation--SMALL dams--to try to bring back some of the resources that one hundred years ago made the first London mining engineers settilng here call Lake county The Switzerland of America. 


\begin{abstract}
In response to your advertisoment in "Lettere To The Editor" in a 11 lako County pepers requesting response to some of the portinent questions regording jeothermel development, the Lake County Enorgy, a 1400 member orgenization concerned with intelligent planning and environmentally oound deve lopment of our onergy resource oxtends to you and your group an Invitetion to attend a public mooting of concerned citizens to present your questions and liston to their ouggestions in an open forrm of diecuseion. If the 1dea 18 useful to rour study, the Energy Douncil will sponsor, arrenge end publicize euch an event. To properly promote the occession we would ask for a throo wook load time.
\end{abstract}

As for your obtaining a sampling of opinion from pooplo in Lake County who buy and read newepapers, write lotters to oditors or others, are eware and Interested in the ocio-oconomic effects of Geothermal derelopment and have an opinion to ohare, the Lake Oounty Energy Council io pleasod to partic1pate in your aurvey on that level too.

Obvious ly there 10 neod for now energy oources. Even if national emphasis were chenged to one of energy conservation and allocation rether than attempting to increase aval lable energy to meot the over increasing demande of oxpanding consumer-production oconomics, wo will omoday oxhaust our ava1lablo fose1l fue 1 roservós. Goothormal power, properly developed, can be a Polatively clean, Inoxponsive altornative ourco whlch may, whon fully utilized provide from 3 to $5 \%$ of the nation'e energy roquiroment. The hazards of Goothermal onergy production are preferable to those of nuclear power and usuelly tho flante are cloaner than coal and other fosall fuel generating operetions. That does not, however, moan thero are no problome asoociatod vith seothermel deve lopment as en energy oouroo.

Geothermal onergy production presents unlque lempet problem for the area to be developed in that the otoam fields utilized for the power cource and the genereting plants must bo at the same ito. In lake County, which is not an unhabited wasto land but 10 the heart of the developing Geysoro KGRA, this presente grave problems of cholce and planning. Storm flelde and generating plants are not compatible with other land uses, ospecially not with residential use. Airborno pollutante, particularly malodorous H2S aro relesced, dispersed and percelved over many miles. Exceseivo jot-ilke 
(2)

nols6 frow wolls venting to the atmoophere during testing, periodic cleanout and during power flant shutdowns are utterly unecceptable. Damege to vetershed, siltation of tributaty and collector streams, increased errosion due to jor grading, filling and compacting operations on roads, well pads, above ground pipe line waye and resultant siteretion of natural drainage, watel courses and ground cover are serious onvironmentel end ultimately economic problems. The several oquare mile area oncumbered by a field and genereting pient is effectively removed from any other use. A wush greater impacted area surrounding each field and plant is rolegeted to those land user competible with the devolopment and its conseque nces. The spiderweb of electrical transmission lines emaneting from the projected "up to 20 power plants" located in various parts of the county will certainly heve multifle effecto of ocenic degradation, removal of land avallable for other uses end :ill, as do the other phases of development effectively pre-determine land use and zoning.

Lake County is primarily a rura 1, agricultural, oumer touriot-recreation, second home-retirement comunity. Noro then ha if 1 to 850,000 agres are Iational Forest and leke. It's population is omall-about 26,000; poormedien income of 37,345 ; and old- wedian age 1848 with over $85 \%$ of the population 65 and over. It is urderdeveloped and underfudied with the usual increasing demend for eorvices. There is littlo omployment and lots of public asis tance.

Lake County is a l8o a place of unusuel and raried ocenic beauty, crystaline ere and benign clireto with a low tex rate and low cost of living located within eqsy driving dietance of the bay ares and a such is fast becoming a retirement home center and second home ito to hundreds of now residents who will ultimetely become permenent residents. Herein 18 ono of the koys to the conflict over Goothermal developments land owner 78 . lot owner which tonds a leo to reflect time lived in the county, roason for boing here, income, ejucation and experience level. The earlier resident may look farorably on Geothermel development a a ource of income to be reelized from proviously merginal land through stoam 10080 foes, opeculativo incroase in land ralue, - team royelties or he may be in a business which can 8011 products or eervices to the Geothermal injustry. He may bope the industry will provide employment. He w11l generally have 11 ttle patienco with onvironmentallets, ocologists and planners, and way oay thet if thingo get too bad for him to 11 ro here, he 'Il be rich enough to more awey. Obviously, whaterer their beckground, most of those who hope to gain economlcally from Geothermal devolopment aro for $1 t$. including lake County government which hopes to gain tax revenue and an improved businese-industriel clime to to incroseo omployment opportunitios and thereby real1zo additional oconomic growth. Som lot owners, of course ohare these viewe and add to them the bellef that utility rates and property taxes in the county will go down as a rosult of Goothermal derolopment although there 18 no eridence to oupport this.

Those who have chosen Lake Oounty for what It IS and Invested their time and woney here for those ressons do not wolcowe industrialization. These who are environmentally aware and bave observed or experienoed the prosent Geyeore 
(3)

operation are against 1to uncontrolled oxpansion and otop-out projocte into areas far from the exieting operetions. Those who find coothermal development Incompatible with their land use plans aro against development as they ooe it belng oxecutod. Those who aro physically dietresed by the odor, nolse, จisue 1 blight, traffic or inconvenience they are now experiencing from existing development do not want more of the same. Those who ferr uncontrolled, unplanned dove lopment and $1 \mathrm{tB}$ unpredictable economic and onviromente: consequences are not Geothermal boosters. Those who left the city for lake County's clean onviroment do not want that environsent changed. Those whose land values are depreciating due to Goothermal activitios do not want those activities to continue or expend.

Some are leaving the county and othere are coming to leke County because of "Geothermin"...end it's only beginning to be felt. Yes indeed, Bome are going to $l 080$ and oome are going to benefit.

Without proper planning and zoning protection to keep them in remoto, compatible areas, the ateam flelds, power plant, pipelines and electrical tranemiseion lines w1ll radically change the appearance and character of Lake County.

Tax revenues realized to the General Fund from Geothermal field and plent assessments w11l probably be consumed and budgetod long before they'ro actually collected. It would bo beneficial if county comuntity oervices (hoalth care, jurentlo offenders facility, road repalr, otc.) could bo oxpanded and peid for by Geothermal tax revenues. It would be great is a county-wide property tax roduction would rosult or if the county could raise Its omployee's wage to competo with wore affluent counties. Perhape the county could purchase lake front property and improve touriet facliltios or offer parks, campgrounds, and boat launching as profltable business ontity. Or use the revenue to build up ito own logal dofonso fund. In roality, it's difficult to foreseo any non-budgotod ourplus of Geothermal tax money boing arailablo for any increase in oorvice or for genoral dietribution in any way.

At this itage of exporienced and forocast dovelopment, the Lako County Energy Counc1l does not boe adoguate local benefit potentie 1 to varrant continued Gootherme 1 development. Wo are not prepared to trado lake Oounty for another filled sot on the netional onergy grid. Wo vill opposo continuing development without an oconomicelly end environmentelly oound totel land use plen oncompasing the overall offecte of Geothormal dovelopment in the Geysers KaRA.

Let me know if you can participate in an open form for a variety of opinion here in leke county, and when you wouls prefer the event to take place. Although the Energy Council does waintain a point of view, we aro concerned that all opinion, a 11 allable information bo made part of the public record in the bolief that en lnformed citizenry 10 better prepared to make good judgements bout 1to future. 
June 5,1977

I am writine in response to your open letter of April 4, 1977, In the Lake Record Bee Newspaper.

1. Q. Assuming development will eventually take place, do you feel that a similar tax bonanza will materialize for Lake County?

A. lio tax bonanza will materialize becase the County is on the bottom rung of the tax collectine ladder. The fed and state are on top and will dribble out only small rebates and matchine funds to the County.

2. Q. Do you feel than the benefits of such a dollar influx would outweigh the detrimental effects of development?

A. No. Look at the fed and state mandated laws and regulations. Then look at the County government. See who is picking up the tab for meeting the administrative workload to comply with all of this. The County has been staggering and faltering more and more under this onslaught...trying to meet and carry a burden which neither the fed nor the state have seen fit to fund properly. The costs of an increasing share of this law and regulation implementation fall on the local property tax payer and there is no commensirate rellef in sight.

The Industries which exploit and the agencies of government which regulate the geothermal and every other resource just pass the cost of development and 0 : goods and of administration right back to the citizen taxpayers. The tall is forever waging the dog and biting him too:

3. Q. There have been proposals for use of potential funds, including improvement of 8 chools, roads, Irrigation and property tax rellef. What others deserve support?

A. First, I think the entire cost of 1 icensing, permitting, zoning, compliance checks and administering every aspect of the geothermal Indiustry in Lake Co. o'ught to be born in fees and taxes paid direct?y by the industry. It should pay. Its way and for ity own policing.

Second, in the event any revenues then are "surplus" that other property tax payers be given tax relief, elther in the form of a rebate or in assessment reductions. 
4. 2. That other programs deserve support?

A. The Lake County Public Library in Lakeport is wholly useless as a research center on the geotinermal activities in the county. The Board of Sunervis ors and the planning Commission in particular ought to be required to place coples of all their meetings, zonIng ordinances, planning reports, environmental assessients and impact statements and revievs, public studies on file for public reference at libraries in all the :or towns in the county.

Presently residents and citizens aro paying anywhere from $50 \$-\$ 3.00$ per sheet for copies of any $k$ ind of public docliment obtained from the County Seat. At these prices no one can afford ot obtain much information. The Lake Record Bee, the official county newsonper, and others in the county are very poor sources of factual news reporting and editorials are nearly wholly lacking as they relate to the geothermal industry, or for that matter any other.

inough tax revenue from the geothermal industry aght to be set aside for the se purposes...to keep the public in a position where it can inform itself. What little info that trickles out between the cracks of the walls of Industry and goverment al agencles as akin to the knowledge of the $J_{A}$ rk Ages.

5. 2. What are the 1mplications of increased dependence on geotherma I tax revenues if it should happen tht the resource be depleted?

A. The Imolications are the same as for any other nonrenewable resource. When the resource is used up and jobs and property and tax bases are gone a chunk of society dies in the aftermath. Look at mining, lumber, agriculture... whatever. Those that depended for their Iivelihoods on 1t--if they dion't save bacte a part. as a hedge against the end--w111 bite the dust... literally.

An additional thnught on 4 above is that the County ought to be made to furnish public notice annua? ly a total financial picture of credits and debits of al1 revenues and expenses, from whatever source, on every County program. There is not now any such puilic accounting of where our dollars go. It is rediculous to try to be informed whthout this data. There is no way of assessing the magnitude and relative strength of programs or priorities. 
Gentlemen:

Apr11 14, 1977

Very briefly, I realize this should have gone in sooner, an replying to your add in the March 1977 Lakeport paper, as to an input toward your findings on an energy program (the geothermal development in Lake County.

We feel this subject has been too long neglected in the way of golng forward and helping in our energy problems, our very difficult financial problems ir.' this county and a help in a very positive way.

Right from the beginning, about 10 years ago, it started right at the very beginning to be a poli.tocal foot-ball, especlally with one young lawyer using it at every opportunity as a climb up the ladder to a goal he has set. Right here is one of the many reasons we dikpt trust the government and all the men that we are supposed to elect, ${ }^{\text {But }}$ that is beside the point just now, back to the issues:

Guestion one: illl sore henefit ara others loose with the develorent of feothermal? I helleve every one will benefit, elther directlr or Indirect, through taxs, etc., and schools, as well as property owners. In tinis day, througn study and working together, what over problems there are, can be worked out. At this time there is one groud in this cainty that has gone by many titles, and also wanv radicals at work, always led by one opoortunistic person. as one radical falls by the way, two more ppear, and they never heve helped a bit. State they will agree'If', but nothing erer w11 olease them. It appears to us that this group, (now under another new name claiming 1500 members (from a 27,000 population) are trving to five our new-found energy to the sate, regardless of 48 that here worked for yeara to buy the land, Improve and pay high taxs on same. It seems as tho ones who dof not have land don't want those of 48 with the land to make any money from $1 t$. Plus our raliey 18 badly polffed from opray material in agriculture and this a ir her" 18 not al i that healthy. Manv of us ouffer from the epray, have for yeara, and wany woved to other parts, we are moving to the hilla to get away from 1t., and car polluation. Our

family will continue to 11 ve here and our prandchildren, but again on high h1118, the valiev is not all thet hosithy, nor was oven with- 
(2)

out the steam, as this 18 a long-standing problem in the valley, altnough littie is seid of that problem. Cobb was a beautiful it. unt 11 so many people bullt and moved up there, = altnou the smel at times was always there, due to the natural gevesers bolling up for many, many vears. Cars and people (the fastest erowing poor county) pouring in ne re have not helped us a bit. Question 2 . How money would be spent? Well, I hope in school taxs, the taxs in this county are very nign (compared to other areas), and also to help with our co-Ine up muckum to be opened tnis fall. Alos for come type of treining for young people. Host of our young beople have to go else merf to earn a living (althou many Welfare peode are cominf in fros. nearly every state).

The lines changing the lines of the mountalns and rellers: No, I don't. bell ere any mor $=$ than tne people who bullt on Mt. Konoct1, bringlne Ines, roads, otc. up there. That didn't help the landecade. Nor al 1 the bullding of nouses (wostly house trallors last few years.) all the increase in population has not nelped our landscape. Second, all the ones that object an not paying the taxes on the sountalns seen in the distance that we have botn have to work 11 ke dogs to hang onto. If they rant scenery, let ther pay the bill, whlch they would never do. It 18 not, any more unalghtiy, than telephone poles along our roads.

Hy nusband's family came here 65 years ago, and I camo 40 jrs ago. If our envi romentiti (a foollon word, as farmers we were aware of $\operatorname{tn} 18$ long before they found the word) want to hesp our community, work toward solutions and nold dom the population, not throw in rodd-blocks. 
Auguat 31,1977

Ms. Muriel Jordan

Geothermal Association for Lake County

General Delivery

Bottle Rock, Rd.

Cobb, Ca. 95426

Dear Ms. Jordan:

As we approach the end of our first year on the Lake County profect, It occurred to us that it may be beneficlal for Lake County to take a serlow look at her future. Whlle we are ostensibly otudying the effects of geothermal development in Lake County, such a task description 18 of IImited scope. The controversy over geothermal is only one aspect of a much larger lasue - rational planning for Lake County.

Our study consequent1y, has taken on a much larger format. We are in the process of looking at Lake County residents' vlews of and hopes for the future, which they express in a mititude of ways. We find their hopes and fears expressed in conversations, letters, editorlals, atc1tudes toward outsiders and Implled attludes regarding change in their 11ves. We have been forced to go outside the normal patterms of social analysis and Include assessments of cultural change, value perception, quallty of IIfe and the flow of benefits and costs within the county.

One of the sallent characterlstics of Lake County is 1 ts apparent polarlastion relative to the geothermal 1asue. Friends and nelghbors are turned against one another because they have placed their hopes in or exist in fear of a technological change. It seems to us that lake County can 111 afford the existence of such a dichotomy. It is conceded by most that Lake County has a geothermal resource, but its existeace, per se, 1s not the root cause of most of the positive and negative aspects of Iffe In Lake County. Issues of planning for the future are raloed In a multitude of commities, but as long as they are percelved as being centered on technological lssues, the discussions are doomed to serles of pro and con arguments.

The heart of our proposal, then 18 that the Geothermal Association for Lake County-co-sponsor along wth any other organiratlons which they deem approprlate, a Lake County Puture Falr and Barbeque. Stch a 
(2)

gathering could be a firot step in getting Lake County to address 1ts pressing planning 18sues. It seems to us important that the two major $e$ energy groups in the county be in the forefront of auch a wove, It would be a good thing for the county as a whole to see that these two groups can work together for the future benefit of Lake County.

As a research group, Hest, Harold and I wll be more than happy to be a resoucce for lining up opeakers and contacting various government and Industry people who might have an Interest in such watter. We wish to emphasize that it is imperative that this falr be of and for the people of Lake County. It 16, after all, the1r (and your) future.

We are a blt unsure as to the approprlate format, but 1 seens that a plenlc with some speakers, music, good food and activity wight be an excellent means of attracting attention to the vital area of planning In Lake County. It often seens that there 10 11mited particppation by the Reneral public in planning, processes, and this falr might provide an opportunity for Lake County's cleleenry to learn and express themselves.

I W111 q1ve you a telephone call about September 9th to hear your reactlons to this Idea, If that would be convenlent. I think that it is Important to Initlate this planning procese relatively soon. Delay only restricts the range of choice.

Thank you for your consideration.

Sincerely yours,

Creg Eacret

for C. West Churchman and Harold Heleon 
August 31,1977

Mrs. Mary Jadiker

Lake County Energy Council

P.0. Box 1184

Clear Lake Highlands, Ca. 95422

Dear Mrs. Jadiker:

As we approach the end of our first year on the LakecCCounty profect, 1t occurred to us that it may be beneficial for Lake County to take a serlous look at her future. While we are ostensibly otudying the effects of geothermal development in Lake County, ouch a task description is of 11mited scope. The controversy over geothermal 18 only one aspect of a much larger lssue - ratlonal planning for Lake County.

Our study consequently, has taken on much larger format. We are in the process of looking at Lake County residents' views of and hopes for the future, which they express in multitude of vays. We find their hopes and fears expressed In conversations, letters, editorlals, att1tudes toward outslders and implied att1tudes regarding change in the Ir 11ves. We have been forced to go outside the normal patterns of social analysis and Include assessments of cultural change, value perception, quality of life and the flow of benefits and costs within the county.

One of the salient characteristics of Lake County 1s 1 ts apparent polarization relative to the geothermal 1ssue. Friends and nelghbors are turned agalnst one another because they have placsd the1r hopes in or-ex1st in fear of a technological change. It seem to us that lake County can 111 afford the existence of such a dichotomy. It 18 conceded by most that Lake County has a geothermal resource, but its existence, per se, 18 not the root cause of most of the positive and negative aspects of 11fe in lake County. Issues of planning cor the future are ralsed In a multitude of comunities, but as long as they are percelved as being centered on technological 1s8ues, the discusslons are doomed to a oerles of pro and con arguments.

The heart of our proposal, then 1s that the Lake County Energy Counc1l co-sponsor along, with any other organizations which they deem appropriate, 
(2)

- Lake County Future Fair and Barbeque. Such a gathering could be a f1rat step in getting lake County to address 1ts pressing planning 188ues. It seems to us Important that the two najor energy groups in the county be in the forefront of euch a move. It would be a good thing for the county as a whole to see that these two groups can work together for the future benefit of Lake County.

As a research group, West, Harold and I w111 be more than heppy to be a resource for lining up opeakers and contacting varlous government and Industry people who might have an interest in such mater. We wish to exphasize that it 18 imperative that this falr be of and for the people of Lake County, It 1s, after all, thelr (and your) future.

We are a b1t unsure as to the appropriate format, but it seems that a plcnic with some opeakers, music, good food and activity wight be an excellent beans of attracting attention to the vital area of planning In lake County. It of ten veens that thereis I1mited participation by the general public in planning processes, and thls falr ulght provide on opportunity for Lake Countybs citizenry to learn and express therelves.

I wll give you a telephone call about september 9 th to hear your reactions to this 1dea, if that would be convenient. I think that it is important to Initlate this planning process relatively soon. Delay only restricts the range of cholce.

Thank you for your consideration.

sincerely gours,

Creg Eacret

for C. West Churchman and Harold Nelson 
SECTION TEN: BENEFIT TRACING

As we stated in the Introduction, it is often the case that costbenefit studies in the highly variable "real world" are reduced to a measure of total or aggregate economic value. While it may be conceded that aggregate economic value is an important measurement tool, it is one of limited applicability because it excludes consideration of the distribution of values. In order to assess the distribution of economic value (dollars), we designed a method of tracing benefits to their ultimate recipients, with the intention of ascertaining the nature and characteristics of the recipients and how the benefit (or cost) comes to them, i.e., who gains and who loses economically. It should be emphasized that economic gains and losses are only a part of the value distribution assessment. For example, the erosion of community and the pessimistic images of many of the citizens are surely "losses," but it is highly questionable whether such losses can be measured in dollars.

Up to the termination of this project, we conducted two economic benefit traces: tax revenues and leasing revenues. Lake County hopes to generate tax revenue from geothermal development at approximately the same rate as Sonoma County has from the Geysers. For Sonoma this has amounted to approximately 3.6 million dollars per year on a production of 500 megawatts. This tax revenue was from all phases of production, leasing, and property evaluation. Fifty-two percent of this tax revenue went to the schools, with a consequent reduction in property taxes. Thus, the true recipients of the benefits were the property owners and not the children in the schools. Fifteen percent went to special districts. We assume that the money was used to pay off debts in the districts and again was used for property owner tax relief. The remainder went into the general fund, and we were unable to ascertain how these monies were used.

It is inevitable that Lake County will face difficulties in allocating the funds which they expect to receive. Claims are coming from many groups and individuals for specific needs: schools, property tax relief, road 
improvement, dam building, environmental cleanup, etc. Proper distribution of benefits needs to be planned prior to their arrival, not with the intent of generating a demand for increased services, but to ensure that no individual or group receives more or less than a fair share of benefits.

Because we believe we have first demonstrated that economic benefits have not been distributed equitably, we believe we have shown the necessity for an ongoing value distribution assessment. In order that there be no confusion as to distribution at any given time, we would like to propose to Lake County an auditing procedure that would enable the county to trace all economic benefits accruing from their tax revenues of geothermal development. An equivalent amount of energy should be spent on tracing the flow of costs in the system, with the intent of lessening their impact.

We also wished to determine who receives money from leasing 1 ands for geothermal energy development. Many of the residents believe that the leasing revenue will go outside the county, through holding companies and absentee ownership, while others are certain that it is the intent of wealthy landowners within the county to exploit the area economically. Others insist that a landowner has the right to take any action on his/her property, and still others say that a landowner has larger social responsibilities. Within this last group are some who assert that social responsibility demands that land be put to its highest and best economic use, and some who fear that the implementation of a "highest and best use" policy will result in the degradation of surrounding land.

There are two other viewpoints which claim members from all of the above classes: one is that government does too much, the other that government does too little.

Information about leasing revenues can provide a means for dealing with the complex issues raised in the preceding paragraphs. In the absence of good information on these matters, the county is suffering another cost: the conflict of neighbor with neighbor. We understand that the California State Energy Conservation and Development Commission has information regarding leaseholds in Lake County, and we also intended to explore other areas mentioned through discussion with local citizens and officials. We hoped through individualized and small-scale discussion to minimize the tendency for sweeping generalizations which might occur if we relied solely on aggregate economics. 
To return to an issue only briefly addressed at the beginning of this section, we recognize that economics is only a subsystem of a larger system such as Lake County. Other subsystems include aesthetics, politics, religion, ethics and ecology, and the performance of each of these is critical to the functioning of the whole system. Given this fact, we are faced with asking questions about each subsystem which are analogous to those asked about the economic subsystem. As an example, we may question the aesthetic effects of development on neighboring property, asserting the interdependence of various pieces of land in generating a total aesthetic experience. We might then explore possibilities for cooperation in promoting the enhancement of various aesthetic goals, possibilities for amelioration of impact or the possibility of cessation of activity.

An initial mechanism for generating such cooperation might be the "value-expert workshop" discussed in Section Four of this report. The calling together of various members of the community and the encouragement of the free expression of ideals for their collective future might provide a healthy base for the planning of options. To set up such a workshop would be difficult, if not impossible, in a polarized community such as Lake County. It seems that most of the issues surrounding geotherma1 development in the county have already-defined positions and personality types ascribing to each position are identifiable. The predictable outcome of meetings on geothermal energy or planning issues in general is the nonsharing of information. The participants instead spend their time in reiteration.

Perhaps one of the keys to understanding this problem is the pre-existing agenda for these meetings. The situation is one where each "side" knows that the others will have specific statements to make about geothermal development and therefore feels compelled to address the same issue. Such attitudes take on the character of self-fulfilling prophecy.

What then can be done to eliminate this rather undesirable state of affairs? An apparent response, to be elaborated upon in Section Thirteen (Conclusion and Recommendations), would take the form of a proposal that these workships and similar efforts be initiated at the beginning of a process of resource development. It may be infeasible to begin long-range planning for each small region of the United States, but as new areas are identified by appropriate agencies as targets for possible development, the residents of the area should be included in an ideal planning process. 
This is an admittedly brief discription of a possible technique, but the critical issue which is addressed here and ignored in the typical approach to development is that of timing. In the typical approach positions are taken, funds are expended, pressures are exerted and decisions are made prior to a clear understanding of the salientissues. To return to the stated focus of this section, benefit tracing; it seems that all parties would be in a much better position to assess the possible benefits and costs of a proposal if the issues were not clouded by misinformation and premature judgment.

As the various communities in the country begin to exhibit a concern for their future, they will inevitably question the wisdom of accepting decisions made by others. When this questioning begins, all parties involved will share in the feelings of frustration with the way in which planning is done, unless the planning takes on the non-reactive character just described. Put alternatively, the costs of the current approach will tend to be even higher in the future. The current ploy of committing funds for development and then claiming a right to a return on the "investment" will begin to backfire as communities refuse to be pushed into development. So too will. the various communities find it increasingly costly to refuse to develop, in terms of lost economic opportunity and reduced range of action in terms of future activity.

Benefits cannot only be traced in retrospect, but the same techniques can be used to assess the wisdom of future choices. It seems quite irresponsible to leave such important questions to chance. 


\section{SECTION ELEVEN: RESPONSE TO ISSUES RAISED BY THE} REPORT OF THE STATE GEOTHERMAL TASK FORCE

The State Geothermal Task Force came into being as a result of Assemblyman Lawrence Kapiloff's bill A.B. 3590 of the 1976 Legislative Session. The bill charged the Task Force with the responsibility for studying geothermal development in California and preparing a report of its findings. The bill required the Secretary for Resources and the Director of the Office of P1anning and Research to submit the report to the Legislature and the Governor.

By law the Task Force consists of the following representatives: three members of the public, two members of the Assembly, two members of the Senate, and one each from the Resources Agency, the State Lands Commission, the Division of $\mathrm{Oil}$ and Gas and the Division of Mines and Geology of the Department of Conservation, the Energy Resources Conservation and Development Commission, the Office of Planning and Research, the Public Utilities Commission, the Department of Water Resources, the Department of Fish and Game, the State Water Resources Control Board, the Air Resources Board and the Solid Waste Management Board.

A.B. 3590 required the Task Force to consider a series of questions concerning four issues:

1. Resource Assessment and Conversion Technology What is the extent, nature and location of geothermal resources? What is the state of existing technology for converting geothermal energy into electric power?

2. Environmental Considerations

What are the environmental constraints on geothermal development and how can development occur with the least possible harm to the environment?

3. Regulatory Issues

What are the best methods of planning for geothermal development? What methods should the State or its agencies require for developing geothermal resources?

Is geothermal development occurring in an expeditious manner? What laws should be amended to encourage expeditious development? 
Should the Public Utilities Commission require utilities to use geotherma1 resources for generating electric power?

4. Economics of Geothermal Development

What economic issues are involved in geothermal exploration and development?

What are the best methods of attracting capital for geothermal development?

The Report of the State Geothermal Task Force contains recommendations for solving the problems associated with geothermal development that were described at the Task Force's four sets of public hearings. For the most part, these recommendations are short-term solutions to immediate problems; they would not radically change the roles of government agencies currently regulating geothermal development.

One or more members of the research group were in attendance at each of the four sets of public hearings. Attendance at these hearings was seen as a means whereby a large amount of information could be accumulated pertinent to the area of geothermal development. As can be seen by the four major questions set down by the legislature, the general tone for the Task Force study was one of interest in smoothing the path for geothermal development. While it may be argued that geothermal energy is the safest and cleanest means of providing for electrical needs in the near future, it seemed that the Task Force had only a marginal concern, at best, with the planning issues raised by the possibility of geothermal development.

As we have seen in earlier sections of this report, there are a multitude of concerns within a community which is faced with such a drastic change as an energy development. It is the opinion of this research group that the Report of the State Geothermal Task Force fails to adequately address these issues, and by this failure perpetuates a poor and/or noneixstent planning methodology at the state level. It is no longer sufficient to plan for economic and environmental effects while ignoring impacts on the social system.

It can strongly be asserted that as one plans for these economic and environmental effects, one also plans for the social system, but this methodology is so circuitous that major issues are systematically ignored or are only encountered when the planning and development are so far advanced that no opportunity for positive adjustment exists. 
In this section we attempt to deal with those areas covered in the Task Force Report which may have hidden social effects not adequately addressed, and to make suggestions for other pertinent information which should be consdered prior to the initiation of full-scale geothermal planning.

The Task Force report's first recommendation is for increased governmental cooperation via a "statewide policy to encourage geothermal development whenever it is consistent with environmental quality standards." Geothermal development is often mentioned as a potential alternative source of electrical power. The Energy Resources Conservation and Development Commission's Biennial Report indicates that utility companies in the state had the capacity to produce an estimated $36,330 \mathrm{MN}$ of electricity in 1975. Peak demand that year was 28,894 MWe.

Power plants operating on geothermal resources produced 500 MWe or about 1.7 percent of peak demand in the same year. In comparison, the utilities produced approximately 2,000 MWe from coal; approximately $20 \mathrm{MWe}$ from combined cycles; approximately 1,000 MWe from gas turbines; approximately 8,500 MWe from hydro plants; approximately 1,000 MWe from nuclear; approximately 2,000 from oil; and approximately $1.054 \mathrm{MWe}$ from pump storage.

The Energy Commission's demand forecast for 1995 is $60,746 \mathrm{MWe}$. The utilities estimate their capacity projections to be 84,880 MWe for 1995 . According to the utilities, geothermal energy will provide an estimated $3,500 \mathrm{MWe}$ or about 5.7 percent of peak demand. In comparison, the utilities expect to obtain 8,500 MWe from coal; 3,500 MWe from combined cycle; 6,000 MWe from gas turbines; 9,000 MWe from hydro; 31,000 MWe from nuclear; 17,000 MWe from oil; 5,000 MWe from pump storage; and 504 MWe solar and wind. There are some doubts as to the viability of the nuclear option. Long-range estimates of California's geothermal potential vary from 12,000 MWe to 19,000 MWe.

The Task Force report asserted that we could expect much more than 3,500 MWe from geothermal development. Implicit in a11 of the above assumptions is the desirability of growth. It was not questioned, either in the hearings or in the Task Force report whether such growth was sustainable or useful. The consequent effects on the social system of the state, with the 
process of growth and accelerated consumption causing large-scale impacts on the communities which are to be utilized as energy suppliers, were not addressed.

\section{ENVIRONMENTAL ISSUES}

Many of the issues raised by the hearings and the subsequent Report were of a technical nature. This is exemplified by recommendations on air quality, health monitoring, water quality, erosion, subsidence, seismicity and noise. To follow through on such recommendations, the various agencies and industries involved would have to increase their monitoring and control activities. This would have a mitigating affect on what might otherwise be completely objectionable conditions in the area of geothermal development.

It is important to realize that Lake County is in large part an undeveloped or rural type environment and any technological infusion will be immediately noticeable. It is true that the utilities and the government agencies recognize this, but it seems that they do so only on a superficial level, and then only to an extent not economically infeasible. This is perhaps a reasonable view on their part, but the population of an impacted area perceive these various regulations as a minimal and poor representation of those qualities of life which they stand to lose.

The Report mentioned problems associated with 1 and use and indicated some recognition of the conflicts between industrialization and rural usage. No recommendation was made for planning in this area or for possible means of avoiding conflicts. It seems important to do more with the imminent changes in aesthetic qualities than to assert that they will occur. "This is, again, symptomatic of the attitude that "development must take place and we will then mitigate as best we can" rather than viewing the problem as an interrelated one, whose best solutions contain elements of a positive approach to the full range of conditions. Planning with these various aspects in mind can eliminate many of the conflicts we often see in development struggles.

The Task Force made a strong response to the recommendations of a group of archaeologists and Native Americans by issuing the following recommendations: 
The Task Force recommends that the State Historic Preservation Officer with the assistance of the Native American Heritage Commission, investigate and consider nominating areas of special cultural significance to Native Americans for registration in the National Historic Register.

The Task Force also recommends that governmental agencies preparing an environmental report on geothermal projects near a significant hot spring describe the impact of the geothermal project on the hot spring. Such geothermal project environmental reports should describe the nature and content of the spring's waters and whether the source or temperature of the spring will be affected by proposed geothermal drilling in the area.

The Task Force further recommends that the governmental agency approving the geothermal project near a signficant hot spring require continuous monitoring of the spring throughout the life of a geothermal project. If geothermal development harms the temperature, quantity or quality of the spring's waters, the project sponsor should take steps to alleviate the problem.

These seem to go a long way toward addressing the issues of ancient cultural protection. It is further to be hoped that government and industry will remain open to other suggestions for the protection of elements of historical and cultural interest.

The Task Force report also considers the protection of fish and wildlife to be important, and to that end proposes that all monitoring programs for the protection of fish and wildlife be under the supervision of the Department of Fish and Game.

\section{REGULATORY ISSUES}

The Report went on to explain the various phases of development and recommended that the permit granting activities of the various governmental agencies be coordinated to expedite the approval of development. We see this as a positive step only to the extent that such coordination enables people to see geothermal development not as a piece meal process but as a whole. Only with this viewpoint can people be expected to make rational choices regarding the appropriateness of energy siting.

It is becoming increasingly recognized that the public must have a say on issues by which it is directly affected. The Task Force called for the addition of three public members to the Geothermal Resources Board, which has been designated to oversee the above permit approval. This will tend to improve the quality of decisions made by the Board. 
The Task Force further recommended a more complete cooperation by federal and state agencies, including non-duplicated applications of various provisions of CEQA and NEPA. This recommendation is once again directed at the expeditious processing of development proposals. To the extent that it speeds up the process, thereby limiting public access to the deliberative process, the goal of protecting and enhancing the social system containing the proposed development will be counter-indicated. If the proposed realignment puts information in a central and accessible place, enabling citizens to inform themselves and make intelligent decisions regarding development proposals, then the change will tend to benefit the system.

The Task Force recommendation that the local jurisdictions adopt zoning ordinances designating areas for geothermal development and requesting the state to provide funding for same can only have positive effects, if the law is worded to preclude the state making the money contingent on the designation of specified acreages to be zoned "geothermal." If these local governmental entities are free to zone as their populace deems appropriate, there will then exist a rational means for assessing the total impact of development. One would expect that the issues pertinent to geothermal siting in a rural community would come out in the context of the zoning hearing, and that conflicts in land use could be handled prior to the issuance of permits. This would further enable both industry and the public to know the limits of the proposal and the consequent limits on the scope and course of development.

The recommendation of the Task-Force that the State Energy Commission's jurisdiction be contingent on the filing of an application for approval of construction of a geothermal power plant further clarifies the relationship of state and local authorities when making a siting decision. This recommendation enables the local government to retain control of the project's development until such time as the project enters its final stages.

\section{ECONOMIC ISSUES}

The bulk of the recommendations contained in the Task Force report concerning economic issues were directed to the elimination of those economic conditions which make it difficult for geothermal operators to 
compete on equal terms with other energy sources. The obvious implications of such a policy (albeit generally stated) are the eventual increase in the ability of geothermal developers to finance more elaborate schemes for development, including highly sophisticated presentations of the potential value of their projects. It is to be hoped that this would also free additional funds for creative planning and environmental control measures which would make geothermal energy a less objectionable part of the Lake County scene. 
SECTION TWELVE: CONCLUSIONS AND RECOMMENDATIONS

As a result of this study, the research group has come up with the following list of conclusions and recommendations.

1) In development planning to date (including but not limited to the development of energy), there has been a serious failure to study and identify the ways in which the residents of the target area might be impacted by the proposed development. Symptomatic of this failure in planning are:

a) views which hold that there exists no entity to protect and enhance (i.e., the existence of the community is not perceived by the planners and is therefore presumed non-existent):

b) definitions of community which only address physical and measurable characteristics and ignore those expressions of a spiritual or metaphorical nature. To the extent that the definition of a problem area limits the range of information consideration relevant, the current information flow in energy development planning is limited to that which the energy profession has typically considered valid.

c) expressions of the situation surrounding community and energy development which adhere to the specious comminity/developer dichotomy. The description of the situation constantly possesses the character of conflict, complete with "our side/their side," "good guy/bad guy" and strategies for arousing sentiment for or against a particular position within the decision-making body.

2) The bulk of the public meetings on the subject of energy development are held on working days between $8: 00 \mathrm{a} . \mathrm{m}$. and 5:00 p.m. This exacerbates public involvement and in fact ensures a continuously limited range of input. In direct contrast is the policy of service groups, clubs and other expressions of community, nearly all of which meet at night. 3) It is an error to utilize professionals employed by various private development companies as "experts" in hearings before decision-making bodies. Their presence should be accepted as advocates only, and therefore subject to the same limitations as are other parties to the dispute. 
There exists within the community a wide range of value experts (se Section Three) whose input to the process would be invaluable.

4) If the proposed development is to maintain standards of moral equity, it is essential that the decision makers be presented with information as to the distribution of benefits and losses.

5) As part of any energy development, the planning agency in charge of integrating and promoting the development should be charged with ensuring the preparation of a full-scale county plan. Adequate funding should be set aside in the budget to enable high quality work. Meetings with residents of the area should be held at a time and place conducive to high attendance. 6) To the extent that the United States Department of Energy is proposing, planning or supporting a development or project which would alter the quality of life in a given community, the Department is responsible for the abovementioned county plan. An important issue which this county plan will bring to light will be that of community enhancement: does the proposed development have a positive contribution to make? How does this contribution balance with the costs imposed on the community? An analysis of this type becomes comparable to discussions of possible mitigation measures in Environmental Impact Reports.

7) The convoluted nature of the decision-making process in energy development needs to be further explored and assessed. There seems to be an abundance of duplicated effort and lost time within the overall management of energy development, such that many options are precluded not for any rational reason but rather on the basis of arbitrary considerations, schedule, time pressure or information availability. Research in this area could provide clues as to more effective management schema.

8) There is a large amount still to be learned particularly in the areas of community and quality-of-life enhancement co-evolving with the processes of energy development. It would appear to be in the best interest of the public-at-1arge that the Department of Energy pursue (via research in both theoretic and practical terms) possible options for this type of planning and development. It is further apparent that such an approach would be political on several fronts:

a) increasing concern on the part of the citizenry as to their quality of life and the viability of their community. Concern by the Department of Energy (as expressed through policy and research 
directions) would be viewed by many as a positive sign of the Department's concern for the general citizenry.

b) an equally large group which perceives the "energy crisis" as a real one, however expressed. A move on the part of the governmental agency charged with administering and exploring alternatives to energy development to smooth the friction-laden interface between development and community would be interpreted as a recognition that energy is a part of a large and complex picture. There is probably a large overlap of membership in these two publics.

c) There is a growing body of professionals and planners who perceive their job as one of fending off the inevitable, planning-as-holdingaction, when combined with the other reactive tendency to constantly re-express a conflict and advocate model, leads to plans which are limited in scope and durability. Were the Department to initiate a series of projects as described above, the professions and the academic community might be able to generate plans which more effectively deal with the complex of futures ahead. 
ACKNOWLEDGMENT

We wish to thank all the citizens and officials in Lake County who helped us in this study. We would like to specifically thank all of those who took the time to write or talk with us, in response to our open letters. We also want to recognize the valued assistance from the Lake County Planning Department.

We received extensive information from other researchers working on similar projects, and wish to acknowledge our debt to them for sharing their work.

Officials in various agencies of the state of California and in the regional offices of the Energy Research and Development Administration (now part of the Department of Energy) gave us encouragement in our initial efforts and saved us a great deal of time and frustration.

Our thanks go to Nancy and Sharon for all their hard work in getting the report organized and typed in its present form. 


\section{REFERENCES}

1. Caudi11, Harry M., Night Comes to the Cumberlands, Boston: AtianticLittle, Brown, 1962 .

2. Christiansen, B. and T.H. Clak, Jr., "A Western Perspective on Energy: A Plea for Rational Energy Planning," Science, 194, No. 4265, November 5, 1976, pp. 578-584.

3. Federation of Rocky Mountain States, Inc., Energy Development in the Rocky Mountain Region: Goals and Concerns, Federation of Rocky Mountain States, Inc., 2480 W. 26th Ave., Denver, CO, 1976.

4. Meeker, David 0., Rapid Growth from Energy Projects, U.S. Department of Housing and Urban Development Guide, Washington, D.C., 1976.

5. Myer, Mary Lynne, "A Sma11 North Bonneville Community Faces the Future," Smal1 Town, Vo1. 8, No. 3, September 1977, pp, 4-10.

6. Myhra, David, "Energy Development," Practicing Planner, September 1976, p. 12 .

7. Peelle, E. et al., "Social Effects of Energy Facilities," Energy Division Annual Progress Report, Oak Ridge National Laboratory, ORNL-5129, 1976.

8. Reiff, Isabel S., Managing the Social and Economic Impacts of Energy Developments, Energy Research and Development Administration, Washington, D.C., 1976.

9. Schaenman, Phillip S and Thomas Muller, Measuring Impacts of Land Development, The Urban Institute, 2100 M Street, N.W., Washington, D.C., 1974.

10. Schumacher, E.F., Smal1 is Beautiful, Economics as if People Mattered, Harper and Row, New Nork, N.Y., 1973.

11. Scott, Randa11 W., Management and Control of Growth, Urban Land Institute, Washington, D.C., 1975 .

12. Rust, Edgar and William Alonso, Adaptation of Reversa1: Policies for the Quality of Life in the Economically Declining Part of Montana, North Dakota and Wyoming, The 01d West Regulatory Commission, 1975.

13. Toole, K. Ross, The Rape of the Great Plains, Atlantic-Little, Brown Books, Boston, 1976 .

14. Tribe, Lawrence, H. Corrine, S. Schelling and John Voss (Eds.), When Values Conflict, Ballinger Publishing Company, Cambridge, MS, 1976.

15. Wolf, C.P. (Ed.), \#2 Social Impact Assessment, ERDA-5, 1974.

16. Baldwin, Thomas E. et al,, A Socioeconomic Assessment of Energy Development in a Sma11 Rural County: Coal Gasification in Mercer County, North Dakota, Vo1. I, Argonne National Laboratory, 1976.

17. Bapp, Donald A., Western Boomtowns: Part I: A Comparative Analysis of State Actions, Western Governor's Regional Energy Policy Office, Denver, C0, 1976. 
18. Bolt, Ross M., Dan Luna and Lynda A. Watkins, Boom Town Financing Study, Vols. I and II, Department of Local Affairs, State of Colorado, Denver, 1976.

19. Budnitz, Robert J. and John P. Holdren, "Social and Environmental Costs of Energy Systems," Annual Review of Energy, Vo1. 1, 1976, pp. 553-580.

20. Carrol1, T. Owen et a1., Hand Use and Energy Utilization, Interim Report, Energy Policy Analysis Group, Department of Applied Science, Brookhaven National Laboratory, Upton, N.Y., 1975.

21. Federation of Rocky Mountain States, Inc., "Resource City, Rocky Mountains," paper delivered at 10th Annnual Meeting of the Federation of Rocky Montain States, Glacier Park, Montana, 1974.

22. Gilmore, John S., "Boom Towns May Hinder Energy Resource Development," Science, Vol. 191, February 13, 1976, pp. 535-540.

23. Gold, Raymong L., Social Impacts of Strip Mining and Other Industrializations of Coal Resources, Institute for Social Science Research, University of Montana, 1974.

24. Gilmore, John S. and Mark K. Duff, Boom Town Growth Management: A Case Study of Rock Spawgs-Green River, Wyoming, Westview Press. Boulder, CO, 1976.

25. Houston, Lawrence 0. et a1., The Energy Boom in Southwest Wyoming, Community Planning and Development, HUD, 1976.

26. Houston, Lawrence 0., "Here's What Should Be Done About Energy-Boom Towns," Planning, March 1977, p. 18.

27. Jacobsen, J.J., Systems Methodology for Assessing the Demographic Impacts of Energy Development, BNWL-2084, Battelle, Pacific Northwest Laboratories, Richland, WA; 1976.

28. Kohrs, Eldean, "The Rocky Mountain States' Boom Areas: Problems and Solutions," Environmenta1 Sociology, No. 4, November 1974.

29. McKay, Michael D. and Lawrence A. Brucker, A Local Impact Model, LA-6665-MS, Los Alamos Scientific Laboratory, Los Alamos, NM, 1977.

30. Missouri River Basin Commission, Plan of Study-Yellowstone Basin and Adjacent Coal Area Leve1 B Study, Montana, Wyoming, North Dakota, 1976.

31. Nehring, Richard and Benjamin Lycher, Coal Development and Government Regulation in the Northern Great Plains: A Preliminary Report, R-1981-NSF/ $\overline{R C}$, Rand Corporation, Santa Monica, CA, 1976.

32. Stenehjen, Erik J., Forecasting the Loca1 Economic Impacts of Energy Resource Development: A Methodological Approach, ANL/A -3, Argonne National Laboratory, Argonne, IL, 1975.

33. Wilkinson, Lawrence E., Energy Resource Development for the West, Western Interstate Nuclear Board, Lakewood, CO, 1974.

34. Summers, Gene F. and Jean M. Lang, "Bringing Jobs to People: Does it Pay?," Sma11 Towns Institute, Vo1. 7, No. 3, September 1976, pp. 4-11.

35. Curry, Maufy and Marjorie Greene, A Program Plan for Performing Social Impact Assessment: A Case Study of Coal Development in the Power River Region, BLWL-2084, Battelle, Pacific Northwest Laboratories, Richland, WA, 1976. 
36. Jacobsen, J. Jay, Dynamic Analysis of the Environmental and Social Impacts of Coal Development in the Eastern Powder River Basin of Wyoming, 1960-2010, , BNWL-2084, Battelle-Pacific Northwest Laboratories, Richland, WA, 1976.

37. Luken, Ralph A., Economic and Social Impacts of Coal Development in the 1970's for Mercer County, North Dakota, 01d West Regional Commission, Washington, D.C., 1974.

38. 01sen, Marvin E. and Donna J. Merwin, Toward a Methodology for Conducting Social Impact Assessments Using Quality of Social Life Indicators, BNWL-2084, Battelle-Pacific Northwest Laboratories, Richland, WA, 1976.

39. Beale, Calvin L., The Revival of Population Growth in Non-Metropolitan America, ERS-605, Economic Research Service, U.S. Department of Agriculture, 1975.

40. Caudill, Harvey M., op. cit.

41. Toole, K. Ross, op. cit.

42. Rittel, Horst W.J. and Melvin M. Webber, "Dilemmas in General Theory of Planning," Policy Sciences 4, pp. 155-169, 1973.

43. Rittel, Horst W.J., On the Planning Crisis: Systems Analysis of the First and Second Generations, Institute of Urban and Regiona1 Development, University of California, Berkeley, Reprint no. 107, 1972.

44. Churchman, C. West, "The Systems Approach and Its Enemies," Special Seminar Notes, School of Business, University of California, Berkeley, 1976-77.

45. Churchman, C. West, The Systems Approach, De11 Publishing Co., New York, 1968.

46. Churchman, C. West, The Design of Inquiring Systems, Basic Books, Inc., New York, 1971 .

47. City of Susanville, Susanville Geothermal Energy Project Workshop Proceedings: Final Technical Report, July 13, 1976.

48. California State Geothermal Task Force Hearings, Bill 3590, Kaploff, Sacramento: April 14-15; San Diego: April 28-29; Sacramento: May 19-20; San Francisco: May 26-27,

49. Lake County Geothermal Conference, Public Meeting, Konocti Harbor Inn, Lake County, October 27-28, 1977.

50. Vollintine, L.R., L. Kunin, and J.A. Sathaye, The Lake County Economy: Potential Socio-Economic Impacts of Geothermal Development, LBL-5944, Lawrence Berkeley Laboratory, Berkeley, CA, February 1977.

51. Summers, Gene F. and Jean M. Lang, op. cit.

52. The Sma11 Towns Institute, Planning for Quality of Life and Economic Prosperity in Your Community, Ellensburg, Washington, 1976.

53. Lake County Energy Council vs. County of Lake, Court of Appeal of the State of California, First Appellate District, Division Four, Sup. Ct. No. 13929, 1977. 
This report was done with support from the Department of Energy. Any conclusions or opinions expressed in this report represent solely those of the author(s) and not necessarily those of The Regents of the University of California, the Lawrence Berkeley Laboratory or the Department of Energy. 